\title{
The Technological System of Production and Innovation: The Case of Photovoltaics Technology in China
}

\author{
Mahmood H. Shubbak \\ Faculty of Business Studies and Economics, \\ University of Bremen, \\ Hochschulring 4, 28359 Bremen, Germany \\ Email:shubbak@uni-bremen.de
}

\begin{abstract}
This research paper studies the Chinese technological system of production and innovation in the field of Photovoltaics (PV). It contributes to a better understanding of the emergence and development of the system by utilising three levels of analysis - the institutional framework of the system, the market dynamics of production and deployment, and the composition of innovation related activities. The analysis demonstrates the interrelated roles of transnational factors, local government policies, and research and development (R\&D) activities undertaken by the main actors, in shaping the system dynamics. Tracking the relative position of China in the global PV manufacturing, installation, and technological development, the analysis shows a gap between the growth of China's market share and its modest share of transnational patent applications. This suggests a puzzle, which the paper attempts to answer by inspecting the individual companies in the system against four aspects. First, the dynamic development of their size and performance. Second, the nature of their international involvement through foreign direct investment (FDI) and mergers and acquisition deals (M\&A). Third, their technological specialization within the PV value chain over time. Fourth, the spatial scope of their patenting protection endeavours. The analysis recognises four periods of system development jointly driven by market dynamics and government plans. Behind the continuous growth of the system, there were different driving and moderating factors in each period.
\end{abstract}

\section{KEYWORDS}

Sectoral Innovation System; Solar Photovoltaics; Institutions; Crystalline-Silicon Market; Patent Analysis; Environment

\section{JEL CLASSIFICATION}

L11; O31; O38; Q42; Q48; Q55 


\section{INTRODUCTION}

Renewable energy sources, as wind, solar, and geothermal power, are widely seen as potential solutions to environmental problems. Therefore, they form an essential part of strategies for sustainable development (Jaramillo-Nieves, Del Río, 2010; Lund, 2007; Valente, 2005). China has prominent role in the literature on PV technologies in developing countries, as it experienced dramatic production growth during a very short period. In 2003, China's share in PV global production was less than $1 \%$. However, the country has rapidly built up indigenous capabilities to become the dominant force in solar cell manufacturing in the world since 2008 (Fu, 2015). In 2013, China accounted for $60 \%$ of the global PV production (Jäger-Waldau, 2013). The dramatic growth in China's market share occurred despite a relatively modest growth in its transnational patent applications until 2008. Even with a faster growth rate in the following years, China's transnational patent application share is still far behind the traditional leading countries in the field (Dominguez Lacasa \& Shubbak, 2016; 2018).

This suggests a puzzle, which we attempt to answer by inspecting the individual companies in the system against four aspects. First, the dynamic development of their size and performance. Second, the nature of their international involvement through foreign direct investment (FDI) and mergers and acquisition deals (M\&A). Third, their technological specialization within the PV value chain over time. Fourth, the spatial scope of their patenting protection endeavours. Consequently, the paper utilizes three analytical levels: institutions, production, and innovation.

In the next section, the conceptual framework and literature review are presented. Section 3 introduces the materials and methods used through the paper. Section 4 shows the detailed empirical results concerning the three analytical levels. A discussion of the results is represented in section 5 in a chronological order over four periods. We finally conclude by stressing the main outcomes and implications in section 6 .

\section{LITERATURE REVIEW}

The conceptual framework of this research is built upon the commonly used analytical tool of 'innovation systems', which is a systemic approach originally developed in the end of the twentieth century to analyse innovation processes at national level (Freeman, 1988; Lundvall (ed.), 1992; Nelson (ed.), 1993). Alongside with national innovation systems, regional- (Cooke et al., 1997) and technological/sectoral level (Carlsson \& Stankiewicz, 1991; Malerba, 2002; Malerba \& Nelson, 2011) concepts were introduced. An advantage of the systemic approach is that it includes all the important factors influencing innovation process (Edquist, 1997).

Technological innovation systems (TIS) can be defined as "network of agents interacting in the economic/industrial area under a particular institutional infrastructure and involved in the generation, diffusion, and utilization of technology" (Carlsson, Stankiewicz, 1991, p. 111). Accordingly, the system consists of three main elements: (i) actors and their competences, (ii) their interactions, (iii) institutional framework (Jacobsson. Johnson, 2000). Additionally, Malerba (2002, p. 251) identifies four more building blocks of a sectoral innovation system as: the knowledge base and learning processes, the basic technologies relevant to the system, demand conditions, as well as variety generation and selection processes of technologies, products, firms, and strategies. 
Institutions and institutional set up "are of crucial importance for innovation processes" (Edquist, 1997, p. 25). Institutions can be understood as "the rules of the game in a society" (North, 1990, p. 3) or as "systems of established and prevalent social rules that structure social interactions" (Hodgson, 2006, p. 2). Carlsson and Stankiewicz (1991, p. 109) characterise the institutional infrastructure of a TIS as "a set of institutional arrangements (both re gimes and organizations) which, directly or indirectly, support, stimulate and regulate the process of innovation and diffusion of technology." Public policy instruments, as one of aspects of institutional infrastructure, are classified in three types: regulations, economic means, and information (Vedung, 1998/2010, p. 30-33). Economic instruments can influence both the demand and supply sides (Borras, Edquist, 2013). Moreover, recent discussion in literature (e.g. Reichardt, 2016; Kivimaa, Kern, 2016; Borras, Edquist, 2013; Veugelers, 2012; Flanagan et $a l ., 2011)$ leads to the conclusion that policy mixes are more appropriate to facilitate innovations than using individual instruments. Malerba \& Nelson (2011) argue that government policies can affect economic sectors differently. In the area of renewable energy, public and industrial policy has shown a significant influence on technology development (Johnstone, et al. 2010; Baker \& Sovacool, 2017).

On the other hand, actor interactions and transnational aspects are particularly important for the evolution of TIS. The influence of transnational factors on innovation processes traditionally takes the form of technology transfer through FDI (Blalock, Gertler, 2008; Barell, Pain, 1997). Other channels are: trade in goods, licencing, and movement of people (Hoekman et al., 2005). In the TIS approach, transnational factors are more broadly understood, and include among others: (i) international scientific cooperation, (ii) global mobility of skilled personnel, (iii) transnational corporations, (iv) global production networks, (v) global equipment markets and market competition, (vi) global technology markets (Gosens et al., 2015, pp. 381-383). Examining economic development of six industries, Malerba \& Nelson (2011,p. 1663) identify two different catching-up trajectories. The first is through specialization in particular stages of the global value chain to access external knowledge and markets, building indigenous capabilities and upgrading to higher positions in the value chain. The second is through subsidiaries and joint-ventures with leading multinational corporations.

In a recent contribution, Lee \& Malerba (2017) introduce the theoretical framework of "catchup cycles'. They argue that in the evolution process of sectoral systems, radical discontinuities open 'windows of opportunity', to which the responses by system actors can affect industrial leadership. Accordingly, four stages in industry catch-up cycle can be identified: entry, gradual catch-up, forging ahead, and falling behind. Furthermore, Lee \& Malerba (2017) distinguish between technological, demand, and institutional windows of opportunity.

To answer the research puzzle introduced in section 1, and to understand the driving factors of the successful forging ahead of China in the PV industry, we will use the technological/sectoral innovation system framework considering both the dynamics of political economy and windows of opportunity within catch-up cycles.

Reviewing the literature on the Chinese PV sector, international trade in goods, movement of skilled employees, and FDI were found main channels of the technology transfer (de la Tour et al., 2011). Similarly, Zhang and Gallagher (2016) pointed out that migration of skilled human resources allowed gaining expertise and information in the early stage of China's TIS 
development ${ }^{1}$. Recent studies about the PV technology in China can be divided into four groups: investigations of PV sector development, policy analysis, comparative studies, and network analysis (Table 2.1).

Table 2.1 Research on the PV sector in China

\begin{tabular}{ll}
\hline Main area of interest & Authors \\
\hline & Huang et al. (2016); Zhang, Gallagher (2016); Zhang, White \\
& (2016); Binz, Anadon (2016); Iizuka (2015); Fu (2015); Honghang \\
PV Sector Development & et al. (2014); Wang et al. (2014); de la Tour et al. (2011); Wu, Hou \\
& (2011); Yang et al (2003); Si-Cheng (1987) Wei et al. (1981)
\end{tabular}

Policy Analysis

Comparative Studies

Network Analysis
Shen (2017); Gruss, ten Brink (2016); Qiang et al. (2014); Zhang et al. (2014); Liu, Goldstein (2013); Zhang, He (2013); Fischer (2012); Fu et al. (2012); Huo, Zhang (2012); Li et al. (2011); Zhao et al. (2011); Ren et al. (2010)

Binz et al. (2017); Gul et al. (2016); Quitzow (2015); Gosens et al. (2015); Platzer (2015); Wu (2014); Jang et al. (2013); Wu, Mathews (2012); Grau et al. (2012); Huo et al. (2011)

Shubbak (2018); Dominguez Lacasa, Shubbak (2016; 2018)

Source: Authors' own elaboration

Binz and Anadon (2016) analysed emergence of the Chinese PV industry based on systemic approach, taking into account four key resources for the industry formation: knowledge, markets, financial investment and technology legitimacy. Their research shows that most of crucial knowledge had international origins. Additionally, instead of trying to satisfy small domestic demand, first entrepreneurs decided to use existing networks and trade infrastructure to enter the European and the Japanese markets with their products. Huang et al. (2016) identified three main factors of rapid development of the China's PV sector: (i) change in institutional set up, (ii) technology transfer, (iii) existence of large European market.

While considerable research on PV development in China already existed, it nonetheless mostly considers single aspects of the process at a time. This leaves a crucial part of the story untold. In other words, the dynamic interrelations between different dimensions, as well as the analysis of innovation and environmental aspects had not been adequately addressed in the literature. In this paper, we adopt the TIS framework to incorporate these dimensions. More specifically, we aim to understand the bidirectional interaction between government policy and global market dynamics, and its influence on innovation and environment. The contribution of this paper is twofold: first, it provides a deeper look into the PV system of production and innovation vertically through the different stages of its value chain. Second, it integrates all the building blocks of the TIS concept and expands it horizontally by introducing what I call the "firmodynamics" element(i.e. micro-level analysis that identifies the main firm actors and their

\footnotetext{
${ }^{1}$ Scholars usually highlight the case of SunTech Power Co, which was the global lea der in solar-cell manufacturing in 2010 . The company was founded in 2001 by a Chinese scientist (Dr. ShiZhengrong), who obtained his PhD in renewable energy engineering from the University of New South Wa les in Australia before moving back to China and running a PV start-up business benefiting from the networks and knowledge ga ined from abroad.
} 
economic performance), and the environmental impact element (considering the specificity of the system and its direct relation to climate change).

\section{MATERIAL AND METHODS}

To study the PV innovation system in China, I first consider the development of its building blocks individually. Therefore, I identify the relevant technologies (section 3.1), for which knowledge base and innovation capabilities are accumulated throughout the system development (section 4.3). The system institutions are discussed from a political economy perspective (section 4.1), in order to detect their interrelations with the market dynamics of supply and demand (section 4.2). Furthermore, I identify the main actors in the system, both firm (sections 4.2.3, 4.3.3) and non-firm (sections 4.1.1, 4.3.3), along with their market interactions with international actors. Finally, I combine the individual building blocks into the complete image of the system (section 5), to understand their interactions and overlapping roles in both: the system development (variety generation, selection, and windows of opportunity), and environment protection (section 5.1). Figure 3.1 summarizes the main dimensions of the present study. The remaining subsections of this chapter introduce the definitions, data sources, and indicators used along the paper.

\section{Figure 3.1: The Analytical Dimensions of the PV Production \& Innovation System in China

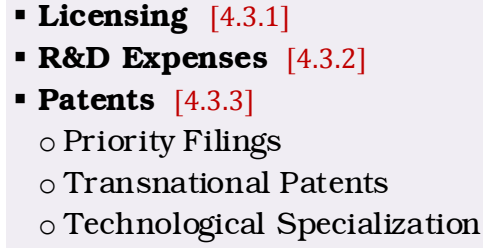

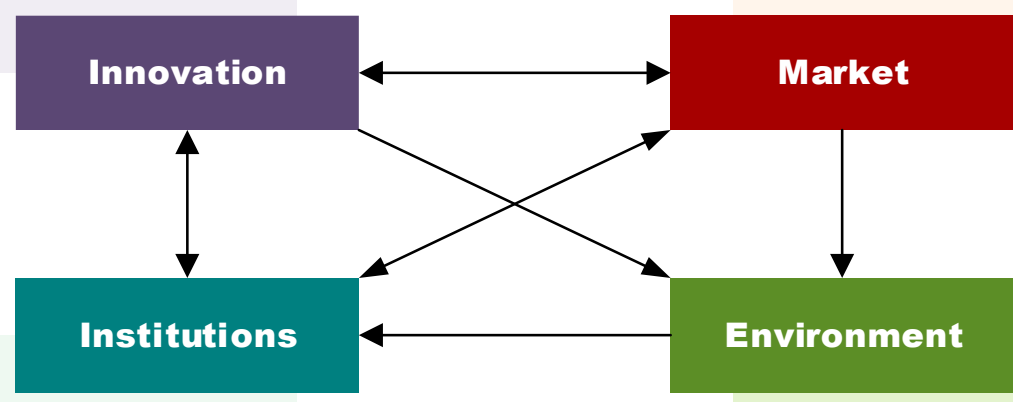

Political Economy:

- CO2 Emissions [5.1]

- Domestic Policy-mix [4.1.1]

- External Shocks [4.1.2]

(IPR, Trade Disputes)

Notes: The relevant subsections a re given in square brackets. The arrows show direction of influence (see table 5.1 for details). Author's own elaboration.

\subsection{PV technologies and components}

To determine innovation activities associated with solar PV technologies, we use the definition and patent identification scheme developed by Shubbak (2017). The classification offers a comprehensive definition of different components along the production value chain of the socalled PV large technical system. It defines six main patent groups for the PV system: (i) solar 
cells, (ii) solar panels, (iii) electronics, (iv) monitoring and testing, (v) energy storage, and (vi) portable devices for lighting, heating and cooling purposes.

These groups comprise subcategories with more details regarding specific technologies. For instance, the first group 'solar cells' represents an active research field in physics, photo- and electro-chemistry. It includes three technology generations with five families differing in their semiconductor materials and manufacturing processes (figure 3.2). These are the relatively mature first-generation $1 \mathrm{G}$ technologies of crystalline silicon (c-Si) cells; the secondgeneration $2 \mathrm{G}$ technologies of thin-film technologies (such as CdTe, CIGS, and Amorphous$\mathrm{Si}$ ) and single-junction Gallium Arsenide (GaAs) cells; as well as the third-generation 3G technologies of the high efficient multi-junction cells and the emerging/organic PV cells (NREL, 2016; Hegedus \& Luque, 2010). These families widely differ in both manufacturing complexity and power conversion efficiency, and thus in their costs, and practical applications.

\section{Figure 3.2: Technology Generations and Families of Solar PV Cells}

\section{$1 \mathrm{G}$ Technologies}

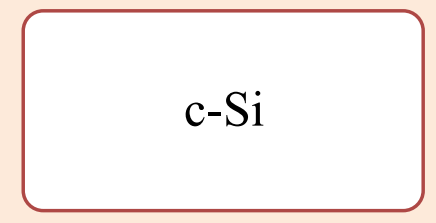

2G Technologies

Thin-film

GaAs
3G Technologies

Multi-junction

Emerging/Organic

Author's own ela boration.

For example, c-Si cells (with cell efficiency ${ }^{2}$ records $\eta \approx 21-27 \%$ ) and thin-film cells $(\eta \approx 14$ $23 \%$ ) are the two families available in mass production. They are commonly used in electronic portable devices, residential solar panels, or utility power plants. On the other hand, the expensive high-efficient technologies of GaAs $(\eta \approx 27-29 \%)$ and Multi-junction cells $(\eta \approx 31$ $46 \%$ ) are mostly used for space power applications (Hubbard, et al., 2009). Organic and emerging technologies $(\eta \approx 11-12 \%)$ are still under development phase in research laboratories. Despite their lower efficiency, the emerging technologies are considered promising due to their low manufacturing costs and additional applications such as transparent cells.

In terms of production share, $\mathrm{c}-\mathrm{Si}$ cells are dominant in the market with $93 \%$ of the total produced capacity in 2015 (69\% multi-crystalline cells and 24\% mono-crystalline), while thinfilm technologies form only $7 \%$ of the total production. Furthermore, China's PV cell production is mostly focused on c-Si technology.

The production of c-Si PV cells goes through three main groups of purification and fabrication processes. In the first, raw materials of quartz sand $\left(\mathrm{SiO}_{2}\right)$ and coal ${ }^{3}(\mathrm{C})$ are processed inside electric arc oven to generate metallurgical-grade silicon, which undergoes further hi-tech processes in several reactors to produce solar-grade polysilicon. The second group of purification processes comprises crystal growth methods, where mono and multi-crystalline ingots are produced. The outcomes of both process groups are called purified silicon feedstock.

\footnotetext{
${ }^{2}$ The conversion efficiency of a solar cell $(\eta)$ is calculated as the portion of the incident sunlight power on cell surfa ce that is converted into electrical energy. In this paper, cell efficiencies source is (NREL, 2016).

${ }^{3}$ Carbon raw material used in this process usually consists of m etallurgical gra de coal a long with charcoal, and coke (Ciftja, et al., 2008,pp.9-12).
} 
The ingots are then sliced into wafers to be doped with $\mathrm{p}-\mathrm{n}$ impurities and soldered with conducting surfaces, which together compose the solar PV cell. Solar panels are produced by wiring and encapsulating arrays of PV cells together. Within all these stages of the value chain, the production of purified silicon feedstock is considered the core technology. It contributes to $40 \%$ of the total cost and $82 \%$ of the final profit of each solar panel (de la Tour, et al., 2011).

\subsection{Market dynamics and firm level data}

To analyse the market dynamics of the system, two levels are considered. First, macro-level data, where indicators are measured per countries. Under this category, three indicators are used: (1) The net charges for using intellectual property (NCIP) through licences based on World Bank, world development indicators database. (2) The market demand-side represented by PV installed capacity based on British Petroleum (BP) statistical review of world energy 2016 dataset. (3) The market supply-side represented by cell production capacity based on the dataset of (Brown, et al., 2015).

Second, micro-level data, where indicators represent the characteristics of individual companies. Under this category, I employ four indicators: (1) Silicon-feedstock production shares of top producers globally, compiled from various resources shown under figure 4.2. (2) Global PV cell shipments of top manufacturers, compiled from various resources shown under figure 4.3. (4) Firm size, performance, and $R \& D$ expenses for the main actors in the system, based on Bureau van Dijk (BvD) - Orbis database (version 129.00). (4) M\&A deals for main global and Chinese firms based on BvD-Zephyr Database (version 30.0).

\subsection{Patent Indicators}

Despite the well-known limitations for using patents as an indicator of technological innovation (Archibugi, 1992), it is undeniable that patent filings act as a key link between successful inventive activities and commercial markets. Patent data covers large temporal and spatial scope, and it includes detailed technical information about the inventions along with their legal and intellectual owners (patent applicants and inventors respectively). Therefore, it provides rich insights into the accumulated knowledge stocks, flows, as well as cooperation activities in the sake of knowledge creation. In this paper, two types of patent applications are considered from the EPO Worldwide Patent Statistical (PATSTAT) Database 2015:

(1) Priority patent filings developed by (de Rassenfosse, et al., 2013) are used to capture the complete landscape of patenting activities per inventor country. Priority filings offer a proxy of the total number of patent families marked by their earliest publications regardless of the issuing authority. Therefore, it can capture a wider scope of patenting activities with various economic and technological values with no restrictions to a specific market domain.

(2) On the other hand, transnational patent indicator developed by (Frietsch \& Schmoch, 2010) covers patent applications only enforceable across national borders. Those are applications filed at the European Patent Office (EPO), and international applications filed under the Patent Cooperation Treaty $(\mathrm{PCT})^{4}$. Therefore, transnational patents are usually

\footnotetext{
${ }^{4}$ Transnational pa tent indicator is ca lculated a voiding double counting of applications that belong to the same family.
} 
expected to be of higher economic and technological value, for which applicants seek protection in several markets across the national borders.

Furthermore, to comparably capture indigenous inventive capabilities, patent applications are fractionally counted and disaggregated by country where inventors are located, e.g. Chinese transnational patent applications indicate patents of Chinese residents that are filed under the international or European patent systems. The fractional counting means that patents, with multiple inventors from different countries, are partly attributed to each country (OECD, 2009, p. 64).

To capture the relative technological specialization of China in patenting activities, I use the Revealed Technology Advantage (RTA) index (Balassa, 1965; Soete \& Wyatt, 1983). RTA is calculated as the ratio between two shares. The nominator is the share of a country's patent applications in a specific technological field over its total patents. The denominator is the share of the worldwide patents in the field over the worldwide patents in all fields. This can be represented by the following formula:

$$
R T A=\frac{P_{i j} / P_{i T}}{P_{N j} / P_{N T}}
$$

Where P: is the number of Patent applications, $i$; represents the inventor country under consideration, $\mathrm{N}$ : represents all inventor countries, $\mathrm{j}$ : represents the technological field under consideration, and T: represents all technological fields.

Laursen (2015) introduces adjustment to the index to become symmetric around its neutral value by using the formula for symmetric RTA (sRTA): $s R T A=(R T A-1) /(R T A+1)$

Accordingly, a positive sRTA indicates that the country has a relative advantage in the technological field compared to other countries. In other words, it means that the concentration of patenting activities by the country in the field $\mathrm{j}$ is larger than the world's average. On the other hand, a negative sRTA means the opposite.

\section{THE PV TECHNOLOGICAL SYSTEM OF PRODUCTION AND INNOVATION IN CHINA}

To understand the PV technological system of production and innovation in China, the paper considers three levels of analysis (figure 3.1). First, I investigate the institutional side of the system. Second, I consider the market dynamics of production and deployment from the macro to the micro level, identifying the main firm actors (producers) and their characteristics. Finally, for the third analytical level, I study the innovation related activities within the system, identifying the main innovators along with their technological specialization.

\subsection{The Institutional Framework}

The first analytical dimension to consider is the institutional framework. Adopting a political economy perspective, I first review the main policies and laws promulgated by the Chinese government regarding PV technologies development and deployment over time. Second, I highlight the external shocks in terms of institutional dynamics, trade disputes, and decisions taken by international parties and their impact on the system of production and innovation in China. 


\subsubsection{Domestic Policy-Mix}

China's commitment to develop and deploy renewable energy technologies has long been institutionalised in government strategies. To analyse the role of the Chinese state in the PV technological system, I consider its main plans, laws, projects, and policies during 1993-2017 (Table 4.1). I distinguish between four types of institutional instruments. First, plans and targets set by the government. Second, 'supply-push' policies aimed for supporting development of PV technologies through scientific research, $R \& D$, and facilitating business activities of PV manufacturers (with financing support, materials/equipment duty-free, enterprise income-tax reduction, and investor subsidies). Third, 'demand-pull' policies aimed for supporting deployment of PV technologies through electrification programs, value-added tax reduction, feed-in tariffs (FITs), technology-adoption subsidies, and grid infrastructure development. Fourth, regulatory instruments such as laws and standards.

We consider four periods that are similar to China's five-year plans (FYP). In the first period (1995-1999), the focus was on building a knowledge base for science and technology as well as regulating electric power production and developing devices for rural electrification purposes. Furthermore, China signed the Kyoto Protocol in 1998.

In the second period (2000-2004), the government continued with rural electrification programs and introduced supporting policies to the establishment of solar panel production through tax reduction on PV manufacturing equipment and products. Moreover, the 10th FYP (2001-2005) aimed to enhance the industrial structure and competitiveness, raise R\&D funding to $1.5 \%$ of GDP, and strengthen science-technology-innovation capabilities.

Government policy in the third period (2005-2009) was mainly production and export-oriented. The solar PV industry was included in the catalog of Chinese high-technology products for export in 2006, and a component of the launch of a science and technology cooperation program in 2008. The program motivates Chinese firms, research institutes, and universities to acquire high-tech knowledge through long-term cooperative partnerships and joint R\&D centres with leading countries in the field to stimulate technology transfer.

Later in 2008, the central government launched a recruitment programme for global experts entitled 'Thousand Talents Plan'. Offering full-time positions (with high salaries and benefits) at research institutes, universities, and national industrial parks, the programme was successful in attracting 4,180 experts by mid-2014. Many of them were overseas Chinese who obtained their higher degrees at western universities. Ball, et al. (2017) highlight the role of the programme in attracting back prominent researchers in PV cell technologies that are less developed in China (e.g. $2 \mathrm{G}$ technologies) to trigger catching-up capabilities ${ }^{5}$.

\footnotetext{
${ }^{5}$ e.g. Zhengxin Liu (expert in Heterojunction with Intrinsic Thin-layer HIT cells from Japan), Xudong Xia o (CIGS cells from USA), and Deliang Wang (CdTe cells from Germany). (Ball, et al. 2017, p. 86)
} 
Table 4.1: The Chinese Policy-Mix for PV Technology over 1993-2017

\begin{tabular}{|c|c|c|}
\hline Year & Policy & Type \\
\hline 1993 & Science and Technology Law & Law \\
\hline \multicolumn{3}{|l|}{ Period 1} \\
\hline 1995 & $\begin{array}{l}\text { 9th five-year plan: speed up the establishment of a modern enterprise system, support } \\
\text { education, focus on scientific and technological research (plan period: 1996-2000) }\end{array}$ & State Plan \\
\hline 1995 & The China Electric Power Law & Law \\
\hline 1996 & Brightness Electrification Program & Electrification \\
\hline 1997 & National Basic Research Program (973 programmes) & Research \\
\hline \multicolumn{3}{|l|}{ Period 2} \\
\hline 2001 & $\begin{array}{l}\text { 10th five-year plan: enhance the industrial structure and competitiveness, raise R\&D } \\
\text { funding to } 1.5 \% \text { of GDP, and strengthen STI capabilities }\end{array}$ & State Plan \\
\hline $2001-2003$ & Reduced Value-Added Tax for Renewable Energy & Tax Reduction \\
\hline 2002 & Township Electrification Program & Electrification \\
\hline 2003-2007 & Preferential Tax Policies for Renewable Energy & Tax Reduction SP \\
\hline \multicolumn{3}{|l|}{ Period 3} \\
\hline 2006 & $\begin{array}{l}11 \text { th Five-year Plan: wider openness in science } \& \text { technology. Energy-saving and } \\
\text { environmental protection. PV power plants in remote areas. }\end{array}$ & State Plan \\
\hline 2006 & Catalog of Chinese High-Tech Products for Export includes PV industry & Strategy \\
\hline 2006 & Renewable Energy Law & Law \\
\hline 2006 & Renewable Energy Price Subsidies and Cost-sharing Management Pilot Scheme & Subsidies \\
\hline 2007 & National Climate Change Program & Strategy \\
\hline 2008 & International Science and Technology Cooperation Program for Renewable Energy & Strategy \\
\hline 2008 & Energy Conservation Law & Law \\
\hline 2008-2018 & Thousand Talents Plan: Recruitment Program of Global Experts & Strategy \\
\hline 2009 & $\begin{array}{l}\text { Renewable Energy Law (Amendment) } \\
\text { (scientific and technological research to be commissioned by government) }\end{array}$ & Law \\
\hline 2009 & Renewable Electricity Surcharge & Subsidies \\
\hline 2009 & Concession Program for Large-Scale Solar PV Power Plants & Subsidies \\
\hline 2009 & Solar Rooftop Subsidy Program & Subsidies \\
\hline 2009 & Golden Sun Demonstration Program & Electrification \\
\hline \multicolumn{3}{|l|}{ Period 4} \\
\hline 2010,2011 & 12th five-year plan: raise renewable and solar energy generation capacity & State Plan \\
\hline 2010 & Building Integrated Solar PV Program & Subsidies \\
\hline 2010 & Taxation preferential policies for renewable energy related enterprises & Tax Reduction SP \\
\hline 2010 & Interim Feed-in Tariff for 4 Ningxia Solar Projects & Feed-in Tariff \\
\hline 2011 & Nationwide Solar PV National Feed-in Tariff & Feed-in Tariff \\
\hline 2012 & $12^{\text {th }}$ Five-Year Development Plan for the Solar Photovoltaic Industry & State Plan \\
\hline 2012 & $\begin{array}{l}\text { Interim Measure of Distributed Solar Power Generation On-grid Service Agreement: } \\
\text { State Grid Cooperation for China (SGCC) announced a plan to allow small-scale } \\
\text { distributed solar power generators to connect to the grid. }\end{array}$ & $\begin{array}{l}\text { Grid } \\
\text { Infrastructure } \\
\text { Development }\end{array}$ \\
\hline 2013 & Renewable Electricity Generation Bonus & Subsidies \\
\hline 2013 & Code of practice of the PV manufacturing & Standards \\
\hline 2013 & $\begin{array}{l}\text { The State Development and Reform Commission's notice on promotion of PV } \\
\text { industry by exert the price leverage effect }\end{array}$ & Strategy \\
\hline 2013 & $\begin{array}{l}\text { Distributed photovoltaic power generation service guide of China Southern Power } \\
\text { Grid Company Limited (Interim) }\end{array}$ & $\begin{array}{l}\text { Grid Infra. } \\
\text { Development }\end{array}$ \\
\hline 2014 & $\begin{array}{l}\text { National certification and Implementation Supervision Commission, Energy Bureau } \\
\text { on strengthening the photovoltaic products testing and certification }\end{array}$ & Standards \\
\hline 2014 & $\begin{array}{l}\text { Notice on issues concerning SGCC to buy distributed PV power generation projects' } \\
\text { electricity products invoice; taxation procedures facilitation }\end{array}$ & $\begin{array}{l}\text { Tax Procedure } \\
\text { Facilitation SP }\end{array}$ \\
\hline 2014-2020 & Energy Development Strategy Action Plan: aims 100 GW installed capacity by 2020 & State Plan \\
\hline 2014-2020 & Poverty alleviation project by installation of solar PV panels in poor households & Electrification \\
\hline \multicolumn{3}{|c|}{ Recent Policies } \\
\hline 2015 & $\begin{array}{l}13 \text { th Five-Year Plan: increase the share of non-fossil fuel energy to } 15 \% \text { by } 2020 \text {, and } \\
\text { reduce carbon intensity by } 18 \% \text { by } 2020 \text {, as compared to } 2015\end{array}$ & State Plan \\
\hline 2016 & Feed-in Tariff reduction $(\approx 10 \%)$ & Feed-in Tariff \\
\hline 2017 & Feed-in Tariff reduction $(\approx 30 \%)$ & Feed-in Tariff \\
\hline
\end{tabular}

Author's elaboration. Source: data compiled from Climate Policy Database (NewClimate Institute); China Intemet Information Center (both accessed in February 2017); (Zhao, et al., 2011; Zhang \& He, 2013; Iizuka, 2015). 
By the end of 2009, the focus of Chinese government policies was shifted towards demand-pull and domestic deployment of the PV technology through the Concession Program for LargeScale Solar PV Power Plants, Solar Rooftop Subsidy Program, and Golden Sun Demonstration Program, where subsidies up to $70 \%$ of the total investment were provided by the government. Both the Renewable Energy Law in 2006 and the Energy Conservation Law in 2008 have clearly set the obligations of different parties connected to the grid, laying down the basis for feed-in operations.

In the fourth period (2010-2014), this institutional transformation was reflected by the 12th FYP with targets to raise solar generation capacity to $21 \mathrm{GW}$ and set up 1,000 'solar energy model villages'. Policies increased in the direction of subsidizing the deployment of Chinese PV panels domestically through introducing FITs, developing grid infrastructure, and implementing a six-year poverty alleviation programme aiming for electrification and raising living standards of poor households through installation of PV panels.

Further policies aimed for supporting the industry through preferential taxation, code of practice for manufacturers, and products testing and certification. The 'China Development Bank' (controlled by the central government) authorized an unprecedented $31.35 \$$ billion in total credit facilities to the leading Chinese PV producers during 2005-2013 (most were accredited in 2010) (Ball, et al., 2017, p. 53). Other state and commercial banks extended debt to PV manufacturers during the same period. Despite the relatively expensive debt (in terms of interest rates compared to that in USA), it nonetheless enabled Chinese companies "to access plentiful debt... at a time when, in the midst of the global financial crisis, most Western solar manufacturers were unable to do the same" (Ball, et al., 2017, p. 51). Chinese PV manufacturers actually borrowed only $14 \%$ of the authorized credit facilities. They used the money to expand production capacity and undertake acquisitions in industrialised countries prior to 2010 , and for surviving the severe recession and overcapacity problems during 2010-2012.

Moreover, a specific FYP for PV industry was issued in 2012 aiming for the construction of 10,000-ton high-purity polysilicon production lines. The PV plan also encouraged the diversification of cell manufacturing by building capabilities in $2 \mathrm{G}$ and $3 \mathrm{G}$ technolo gies. In 2015, China signed the Paris Agreement for greenhouse gases emissions mitigation. Accordingly, given the country's problems with air quality, its 13th FYP in 2015 aimed for increasing the share of non-fossil fuel energy to $15 \%$ and reducing carbon intensity by $18 \%$ by 2020. The plan was accompanied with launching a carbon emission-trading scheme in seven pilot regions in 2016. Recently in 2016 and 2017, the Chinese government announced reductions in the FITs up to $30 \%$. However, its subsidy for distributed solar PV remains unchanged. This dramatic FITs reduction can nonetheless open a new chapter in the Chinese PV story in the next few years.

\subsubsection{External Shocks}

The dramatic growth of the Chinese PV industry and its share in the global market led to significant conflicts with the incumbent leaders, what is often referred to as the PV 'solar wars'. In July 2010, the German Renewable Energy Sources Act was amended, reducing FITs in the 
country in response to the sharp drop of PV panel prices in 2009.6 In addition to its normal annual depreciation, the FIT's reduction varied between $8-16 \%$ based on the installation type. Besides that, the amendment set new constraints on utility-scaled installations, limiting their size to maximum of $10 \mathrm{MW}$, and excluding installations on agricultural fields from FITs (Gründinger, 2015). Moreover, in 2011, several European governments reduced their PV subsidy programs because of the high deficit from the 2009 financial crisis recovery.

Consequently, and since the European countries were accounted of more than $70 \%$ of the global annual installations, the international PV demand declined significantly. In the meanwhile, the production supply was still rapidly increasing. This situation led to a huge overcapacity in the entire PV industry, causing a dramatic drop in prices across the PV value chain. For example, solar module prices dropped about $70 \%$ between the fourth quarters of 2010 and 2012 (Wang, et al., 2014).

Another chapter of the solar wars had emerged in the form of intellectual property right (IPR) disputes. In 2011, Westinghouse Solar Inc. (USA) filed a complaint against Canadian Solar (Chinese subsidiary) and Zep Solar (American PV panels company that licenses technologies to some Chinese firms) alleging them of patent infringement. Zep Solar responded with a lawsuit against Westinghouse Solar and four other parties. Although a final settlement of the legal disputes was announced in 2012, the PV IPR became the subject of extensive debate in the USA when two companies financially aided by the government filed for bankruptcy. Solyndra and Evergreen Solar Inc. received more than \$600 million from the USA government as loans and financial aid packages. They owned several patents in CIGS and string-ribbon cSi cell technologies before their bankruptcy in $2011 .^{7}$

Further, in 2011, a group of solar PV manufacturers filed a trade case against Chinese PV producers for dumping the market with products subsidized by the Chinese government. They claimed that due to the Chinese activities, more than 20 American producers closed or went bankrupt. Following to trade investigation, the USA Commerce Department (DOC) began imposing high tariffs on Chinese imports in 2012. Consequently, the USA imports of solar cells and panels from China declined from \$2,804 million in 2011 to \$1,144 million in 2013 (Platzer, 2015). Later in 2014, DOC announced additional anti-dumping duties (AD) of around 27-78\% and anti-subsidy duties (Countervailing duties CVD) of around 28-50\% on importing solar panels made in China (Cardwell, 2014). In 2013, the European Union (EU) imposed duties of around $48 \%$ on Chinese PV imports due to similar trade disputes. In response, China issues AD duties up to 57\% on solar-grade polysilicon imports from the USA and EU in 2013-2014.

These external shocks affected the Chinese PV industry from both sides. First, Chinese cell manufacturers lost large shares of the international demand, as their prices became less competitive in an already shrinking market. Second, the supply costs of raw materials (purified silicon feedstock from USA) increased according to the Chinese government duties. The critical situation could have led to a collapse in the solar PV industry in China, unless the Chinese government had intervened by stimulating the domestic market (section 4.1.1).

\footnotetext{
${ }^{6}$ The rapid development of a large solar industry in China led to an international decline in PV module prices by approx. $30 \%$ in 2009 .

${ }^{7}$ When a company undergoes bankruptcy, its patents a re usually liquidated, or they expired when nobody pays their maintenance fees.
} 
Interestingly, a recent trade petition in the USA was filed by cell manufacturing firms (Suniva and SolarWorld Americas) in April 2017, seeking 'global safeguard relief' in the form of tariffs on imports of c-Si PV cells regardless of the exporting country. However, what is different this time is that the Solar Energy Industries Association opposes the petition considering any additional tariffs as a threat to the broad PV industry in the country and its 260,000 jobs, which are mostly focused on sales and installation, not manufacturing. The decision on that case, expected to be announced in 2018, might thus have an impact on the PV sector in the USA.

\subsection{The Market Dynamics}

The second dimension of analysing the Chinese TIS in PV technologies is to understand the global PV market dynamics focusing on the position and progress of China in it. On the way to obtain this understanding, this section reviews the demand side of the system represented by the PV installed capacity, along with the supply side represented by the PV cell production. After that, section 4.2.3 discusses the system's firm dynamics by identifying the main Chinese firms and analysing their economic performance.

\subsubsection{Demand Side (PV Installed Capacity)}

Reviewing countries' share of annual installed capacity in the period 1996-2015 (Figure 4.1a), two major shifts can be noticed. In years 1996-2003, the largest share of annual installations was accounted to Japan (ranging between 25-50\%). The first shift was towards Europe, where Germany became the largest market for PV cells during 2004-2012. ${ }^{8}$ The peak of German annual installations was reached in 2010. Such high rate of installations in Germany lasted for three years with an average of 7,500 MWp then it declined dramatically. The second major shift was towards China. Starting from 2009, the annual installed capacity in China has experienced a notable growth (from less than 40 megawatts in 2008 to 15,150 megawatts in 2015). This growth was mainly due to the construction of several PV power plants around the country along with a wide expansion in the residential use of PV panels. The major PV power plants in China (Table 4.2) were established in 2009-2011, and they entered the service in 20132015. Interestingly, since 2015, China has become the world's leader of PV installations with cumulative capacity of over $43 \mathrm{GW} .83 \%$ of the $101.8 \mathrm{GW}$ installed capacity in China by mid2017 are in utility-scale.

Table 4.2: Largest Photovoltaic Power Plants in China until 2017

\begin{tabular}{|c|c|c|c|}
\hline Photovoltaic Power Plant Name & $\begin{array}{l}\text { Capacity } \\
\text { [MWp] }\end{array}$ & $\begin{array}{l}\text { Commissioning } \\
\text { Year }\end{array}$ & Previous Phases \\
\hline Longyangxia Dam Solar Park & 850 & 2015 & Phase I (2013): $320 \mathrm{MW}$ \\
\hline Huanghe Hydropower Golmud Solar Park & 600 & 2015 & Phase I (2011): $200 \mathrm{MW}$ \\
\hline YanchiSolarPV Station & 380 & 2016 & \\
\hline Cixi solarfarm & 200 & 2017 & \\
\hline Gonghe Industrial Park Phase I & 200 & 2013 & \\
\hline Zhongli Tenghui solar farm & 150 & 2015 & \\
\hline Tengger Desert Solar PV Power Plant Project & 100 & 2014 & \\
\hline Chengde PV Project & 100 & 2013 & \\
\hline Jiayuguan PV power plant & 100 & 2013 & \\
\hline
\end{tabular}

Data Sources: (Lenardic, 2016; Publicover, 2017). Author's ela boration.

\footnotetext{
${ }^{8}$ In the period 2004-2012, Germany wa s the largest market for PV cells except for years 2008 and 2011, when Spain and Italy became one-year lea ders respectively.
} 


\subsubsection{Supply Side (PV Cell Production)}

On the supply side, prior to 1995 , the annual PV cell production was less than 70 megawatts largely dominated by USA and Japan. Germany entered the scene in 1999. These three countries continued leading the market until 2005, when new players started gaining notable shares. Figure 4.1b shows the global landscape of PV cell production in the period 1995-2013. Three shifts in the industrial leadership can be noted, from USA to Japan in 1999, to Germany in 2007, and finally to China since 2008. China's share in the global market has been growing dramatically from less than $1 \%$ in 2003 (with $13 \mathrm{MW}$ ) to around $60 \%$ in 2013 with around 27 $\mathrm{GW}$ of production capacity.

\section{Figure 4.1: Global Market Dynamics of the PV sector}

a) Demand Side: Share of Global Annual PV Installed Capacity by Country*

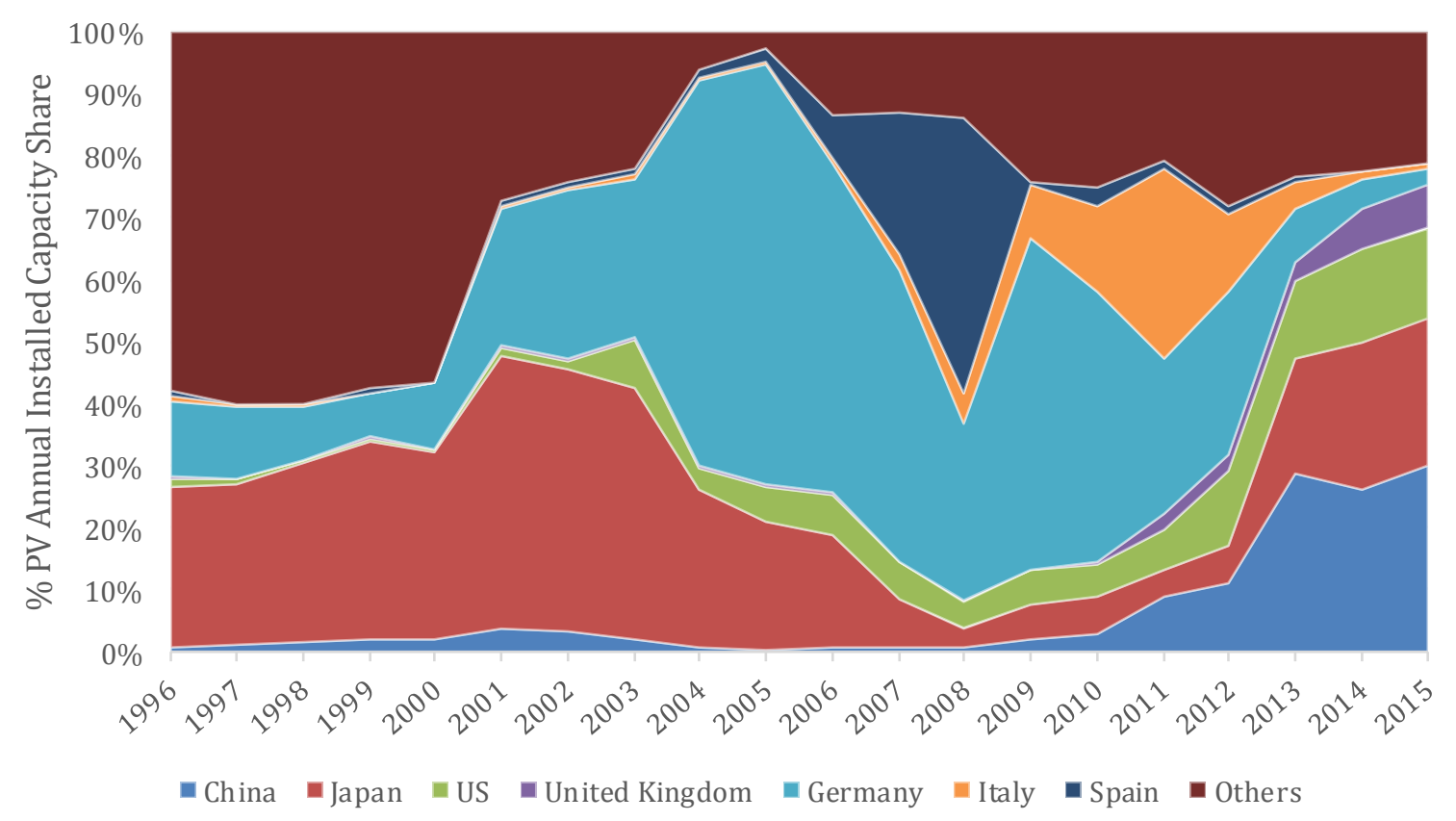

b) Supply Side: Share of Global PV Cell Production by Country**

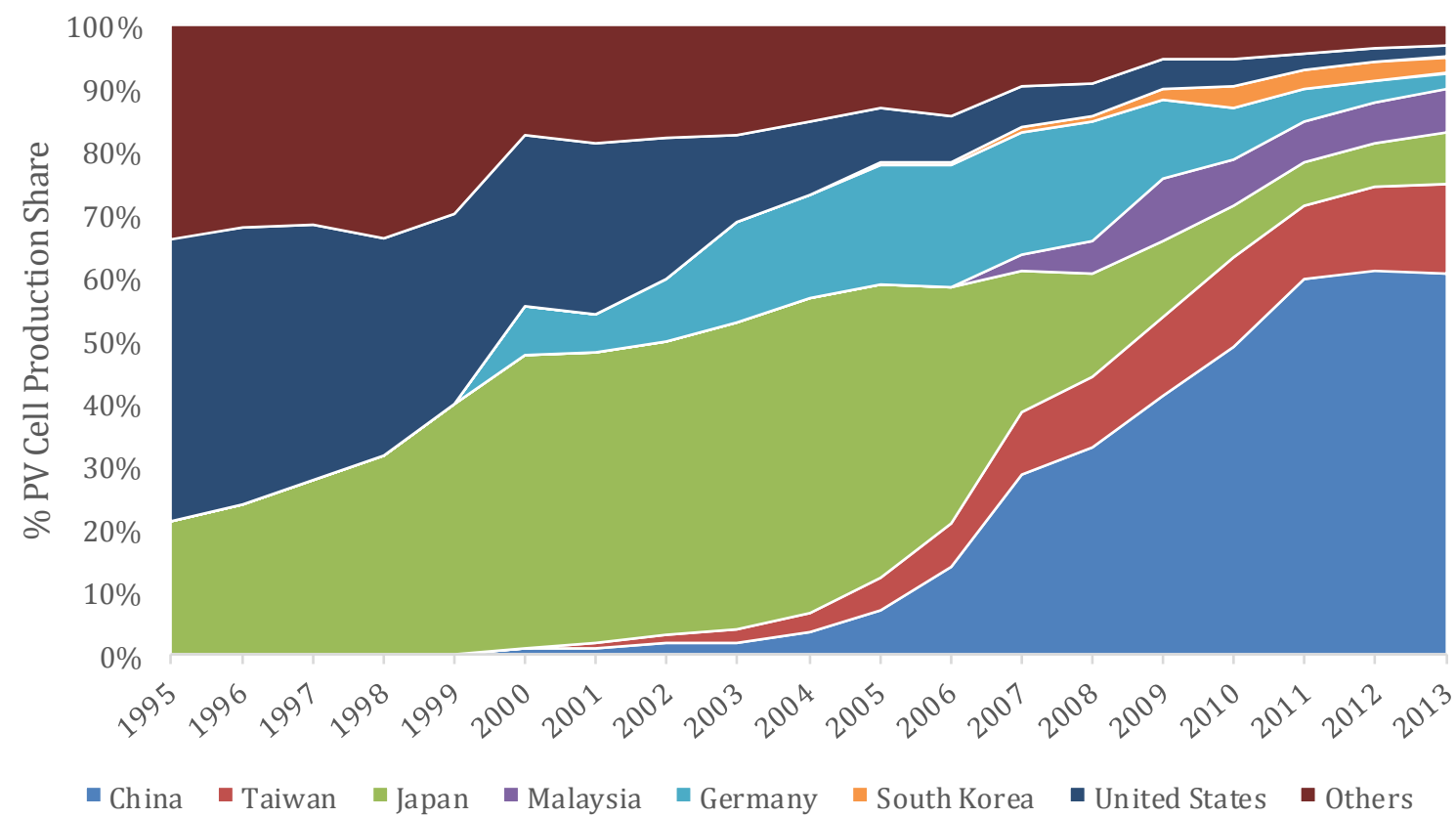

Data Sources *BP Statistical Review of World Energy 2016 **dataset of (Brown, et al., 2015). Own ela boration 


\subsubsection{System Firm Dynamics}

The next step in studying the Chinese PV system is to identify the main firm actors along with their economic performance over time. In the paper, we will refer to this analytical level as the system firmodynamics. To study it, we first observed the PV market from a global perspective, analysing the main silicon-feedstock producers and solar-cell manufacturers according to their market shares. Subsequently, we identified the emergence and development of Chinese firms in the global industry landscape. Having a list of the main Chinese firm actors, we dynamically analysed their size, performance, and international involvement. A complete list of these actors is provided in Table $\mathrm{A}$ in the appendix.

\section{Main Silicon Feedstock Producers}

Zhao et al. (2011) stated that in 2007, more than 95\% of China's polysilicon feedstock relied mainly on importing from overseas. This heavy dependence on international suppliers formed a big hurdle for the Chinese PV industry at its initial stage (Fischer, 2012). However, considering the recent stages, our results show a breakthrough in accumulating indigenous capabilities in running the Silane process for producing solar-grade polysilicon, and finally producing mono- and multi-crystalline silicon ingots. China's share of the global Silicon feedstock has dramatically increased from around 4\% in 2008 to $38 \%$ in 2015 (in light of the government's 12 th FYP for PV industry and the global trade actions discussed in section 4.1.2.)

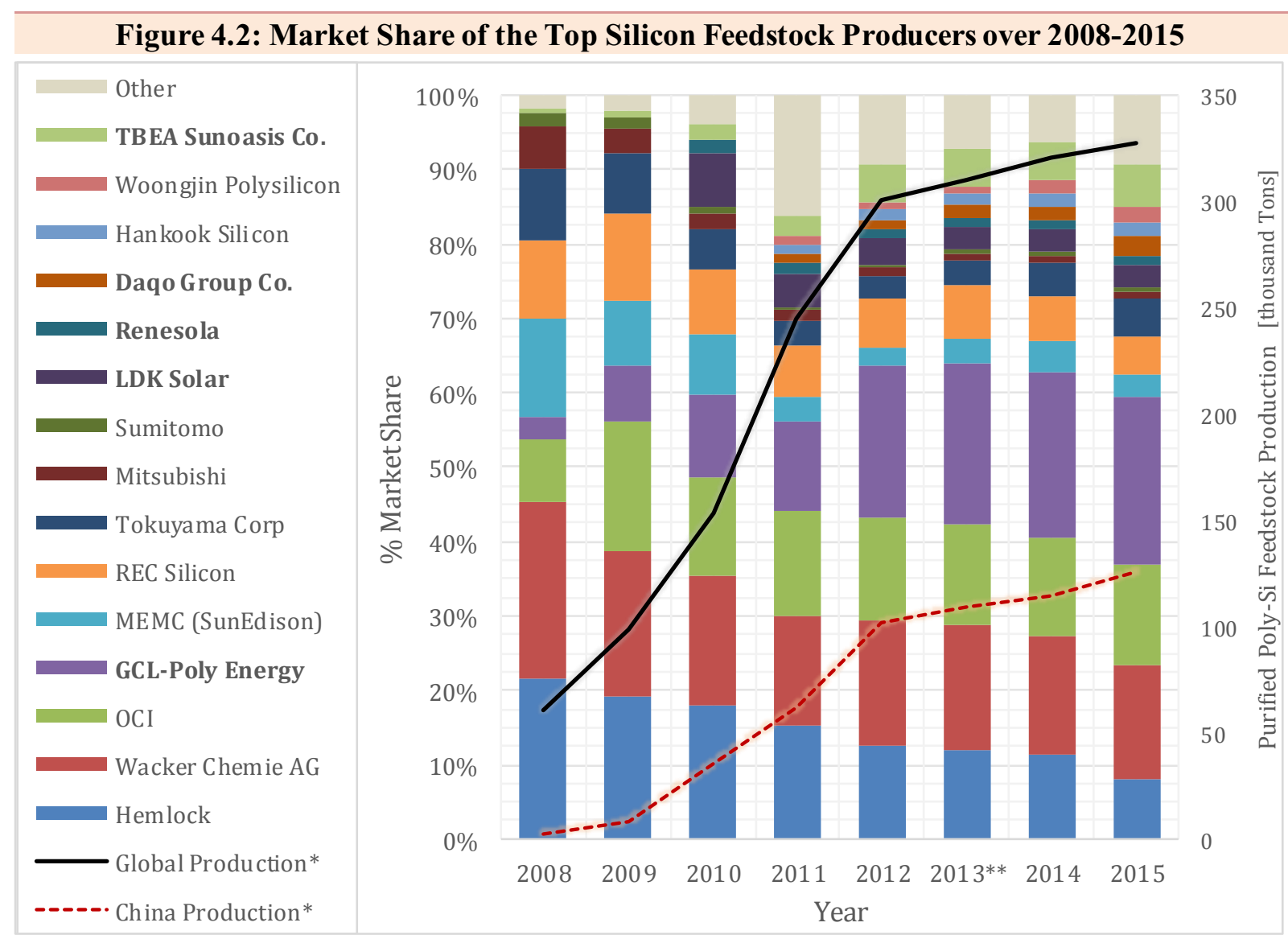

*Figures for Global and China Si-Feed stock Production a re given in secondary axis. **Data of 2013 is estimated. Data sources: Compiled from (Yu, et al., 2016; Roselund, 2016; Park \& Kim, 2012); BvD-Orbis database; Bloomberg L.P. data; Companies' websites, annual reports and fact books (a ccessed in February 2017).

Author's own elaboration. 
Figure 4.2 pictures the feedstock production landscape during 2008-2015. Until 2009, the global silicon feedstock market was dominated by six international firms located in USA, Germany, Norway, Japan, and South Korea. ${ }^{9}$ The six firms were accounted for around $86 \%$ of the global production. However, since 2010, five Chinese companies (noted in bold in figure 4.2) were able to catch-up, expand their production capacity, and gain a notable market share ${ }^{10}$.

Two further notable features of figure 4.2 are that global silicon production experienced a fast growth during 2008-2012, after which it stagnated as due to over-supply in the past period. Second, China's feedstock production, despite obvious progress, still is behind the Chinese dominance in PV cell production.

\section{Main PV Cell Manufacturers}

The global PV market was relatively small before 2000 with around $\$ 2.5$ billion (Statista, 2016). Moreover, the annual PV shipments globally were less than $200 \mathrm{MWp}$ (Brown, et al., 2015 ) with a rate of change of only 30 MWp p.a. during 1995-1999. However, since the beginning of the $21^{\text {st }}$ century, the market experienced a dramatic growth. Empirically, three main stages can be identified since then. First during 2000-2004, the market was growing with a rate of $192 \mathrm{MWp} / \mathrm{yr}$. reaching for the first time the level of $1 \mathrm{GWp}$ in 2004. In the second stage 2005-2009, the rate increased 8-fold to reach the level of 1,652 MWp/yr. Finally, since 2010 , the rate reaches the level of 5,311 MWp/yr. with more than $50 \mathrm{GWp}$ shipments in 2015.

Figure 4.3 shows the market shares of the top ten cell manufacturers over 2000-2015. During the first stage, the market was mainly dominated by six firms located in Japan, EU, and USA ${ }^{11}$. Those traditional leaders together were accounted for more than $60 \%$ of the global market.

The market landscape changed gradually in the second stage, with new firms from other countries (mainly Korea, Taiwan, and China) entering in 2006. Consequently, the share of the traditional leaders declined into less than $20 \%$ in 2007, and even to $4 \%$ in 2011 (third stage) with many of them leaving the market. In the third stage, the market became even less concentrated with several firms from emerging economies gaining notable shares.

Analysing the market landscape (figure 4.3), eight Chinese PV manufacturers (noted in bold in the figure) can be identified during the latest two stages of market development ${ }^{12}$. In 2013, they were accounted for $42 \%$ of the global cell production, which comprises $70 \%$ of the production in China.

\footnotetext{
${ }^{9}$ These silicon feedstock leaders a re Wacker Chemie AG(DE), Hem lock (USA), MEMC (USA), REC Silicon (NO), TokuyamaCorp(JP), and OCI (KR).

${ }^{10}$ These companies are GCL-Poly Energy, LDK Solar, TBEA Sunoasis Co., Da qo Group Co., and Renesola Ltd.

${ }^{11}$ These tra ditional lea ding companies in PV cell production are Kyocera (JP), BP Solar(UK), Sharp Solar(JP), Shell Solar (NL), Astro Power(USA), and RWE/Schott Solar(DE).

${ }^{12}$ These Chinese 'star' firms are SunTech, Ja Solar, Yingli, Trina, Canadian Solar (CSI -Cells), Jinko Solar, ReneSola, and Hareon.
} 


\section{Figure 4.3: Market Share of the Top 10 Solar PV Cell Manufacturers over 2000-2015}

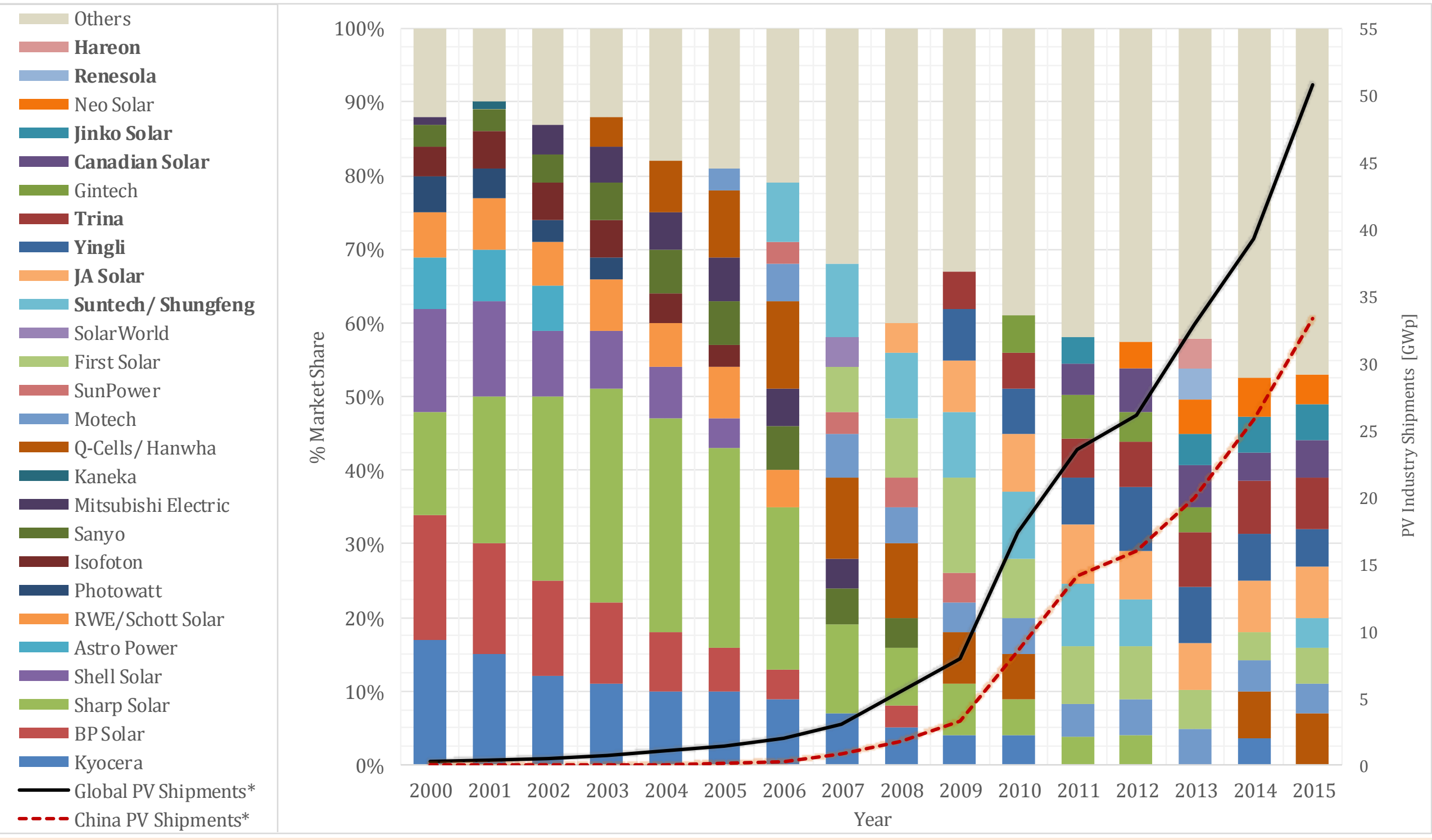

*Figures for Total PV Shipments a re given in secondary axis

Data sources: Renewable Energy World (Mints, 2014; 2016); dataset of (Brown, et al., 2015).

Author's own elaboration. 


\section{$\underline{\text { Size of Main Manufacturers }}$}

PV production and deployment represent a relatively large industrial sector in China with more than 1.7 million employees in 2015 (IRENA, 2016). It takes advantage of the low labour cost in the country (average annual costs per employee varying from $\$ 500$ to $\$ 4,000$ in Chinese PV firms comparing to $\$ 25,000$ in Taiwan and $\$ 80,000$ in Germany ${ }^{13}$ )

To better understand the dynamics of the PV production system in China, the development of manufacturers' size is considered (figure 4.4). The analysis shows a common trend in the number of employees during 2007-2015. Most of the Chinese manufacturers experienced a sharp growth until 2011. The rapid growth was followed by a stagnation period. Starting from levels around 2,000 employees in 2007, the cell manufacturers Trina, JaSolar, and Yingli, as well as the feedstock domestic producers GCL and LDK, all grow to reach levels of more than 10,000 employees in 2011. Yingli achieved the highest growth and became the largest cell manufacturer in China since 2011. Only two exceptions can be seen in the trends: SunTech ${ }^{14}$ and CSI-Cells. In the case of SunTech, the company was considered the largest cell manufacturer in the world before 2009. The size of its main manufacturing unit in Wuxi was 5,000 employees until the financial problems it faced in 2010. Since then, it declined to 2,000 employees in 2011. On the other hand, CSI-Cells, which is a subsidiary of the Canadian Solar Inc., had a stable size around 1,500 employees over the period of consideration.

\section{Figure 4.4: Chinese PV Firms Size: Number of Employees 2007-2015}

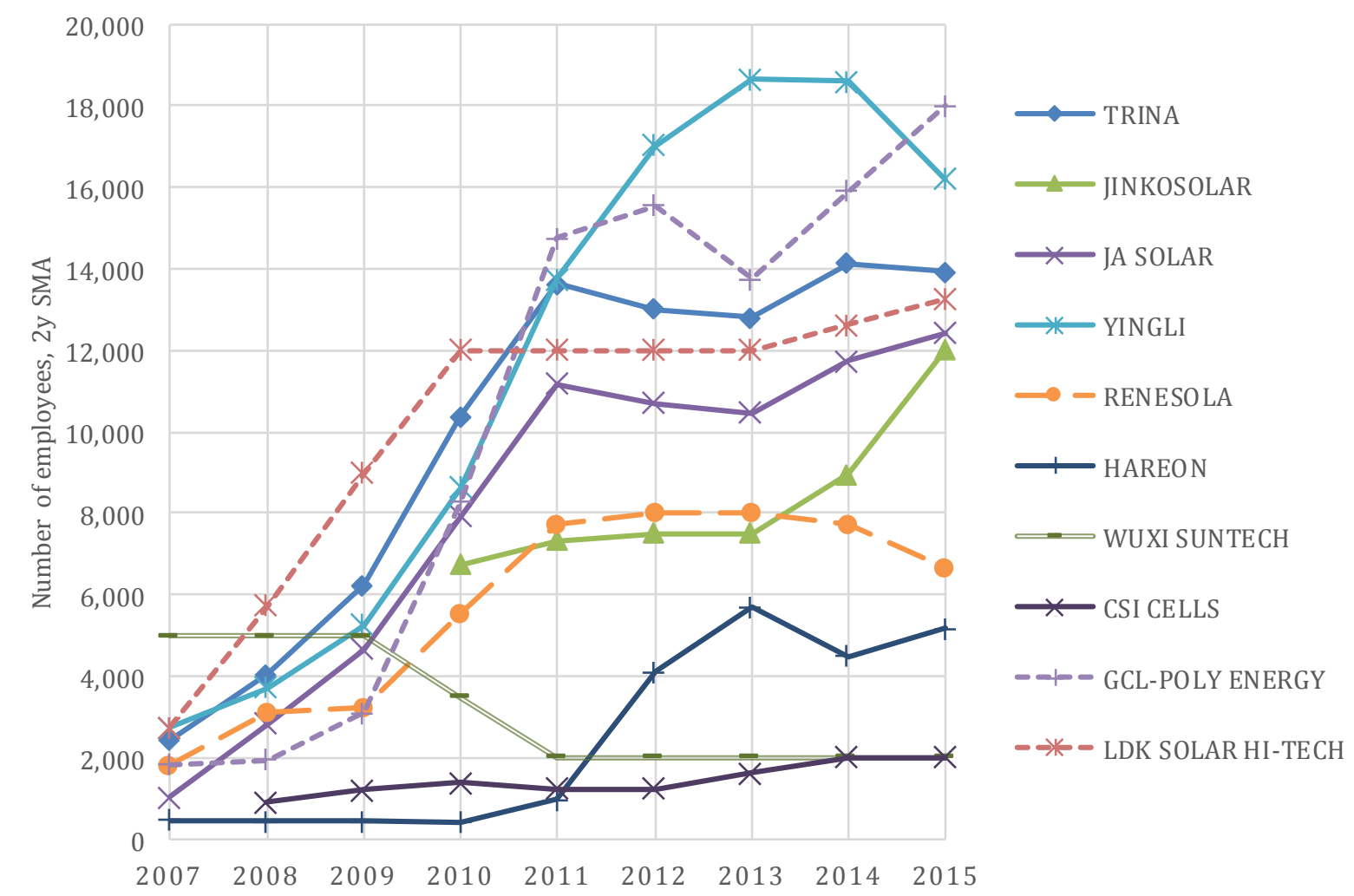

Data Source: Bureau van Dijk - Orbis da tabase (version 129.00). Author's own elaboration.

\footnotetext{
${ }^{13}$ Costs of employees were calculated for the main PV producers using data from BvD Orbis da tabase.

${ }^{14}$ Due to limitations of the database, data for SunTech in figures 4.4 and 4.5 a re only for the company's main production unit in Wuxi, China.
} 


\section{Economic Performance of Main Manufacturers}

In examining the economic performance of the main actors, I consider two indicators: the turnover and gross profit (figure 4.5).

\section{Figure 4.5: Chinese Firms Economic Performance (2007-2015)}

\section{a) Operating Revenue (Turnover) Trends}

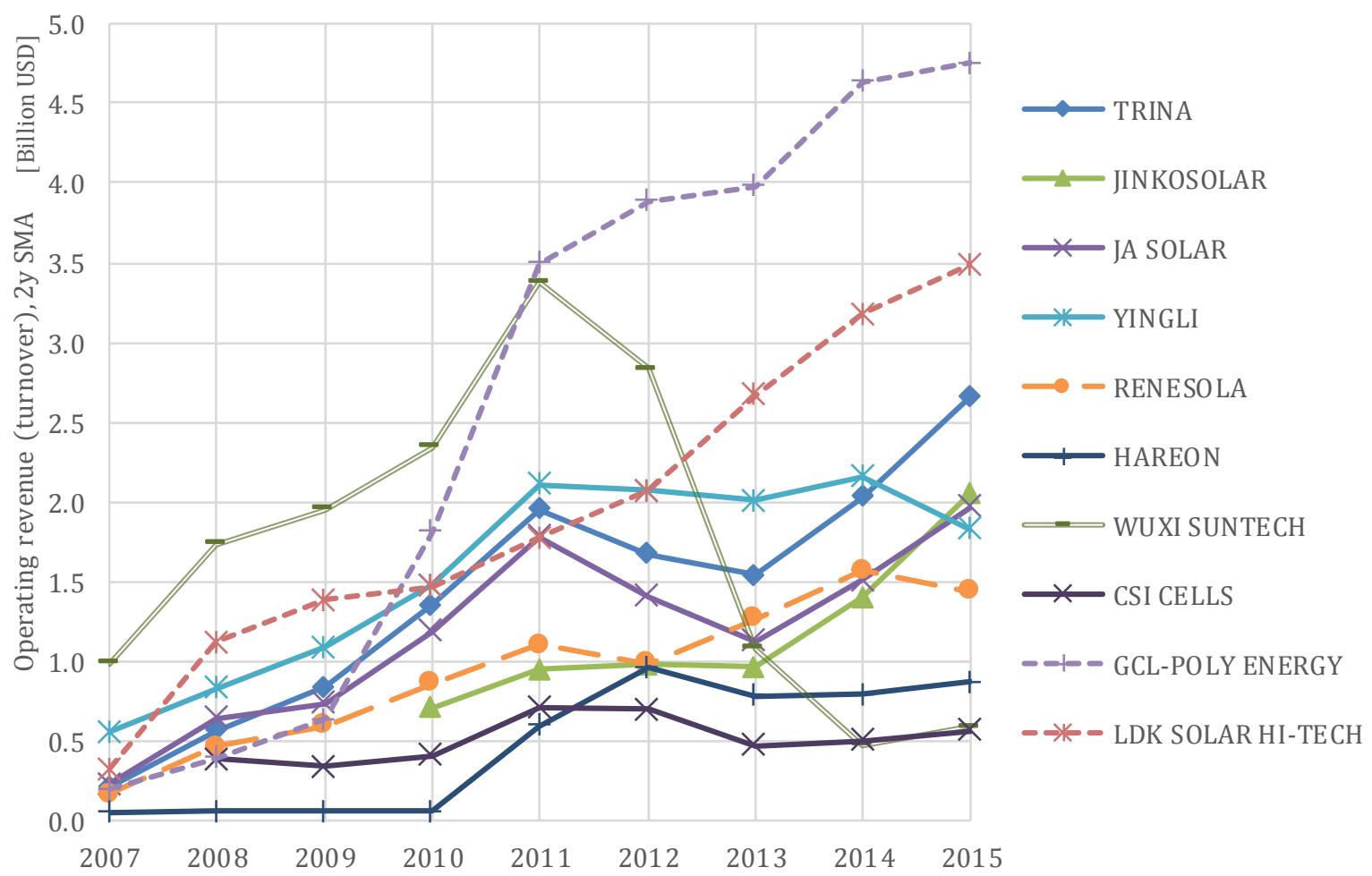

\section{b) Gross Profit Trends}

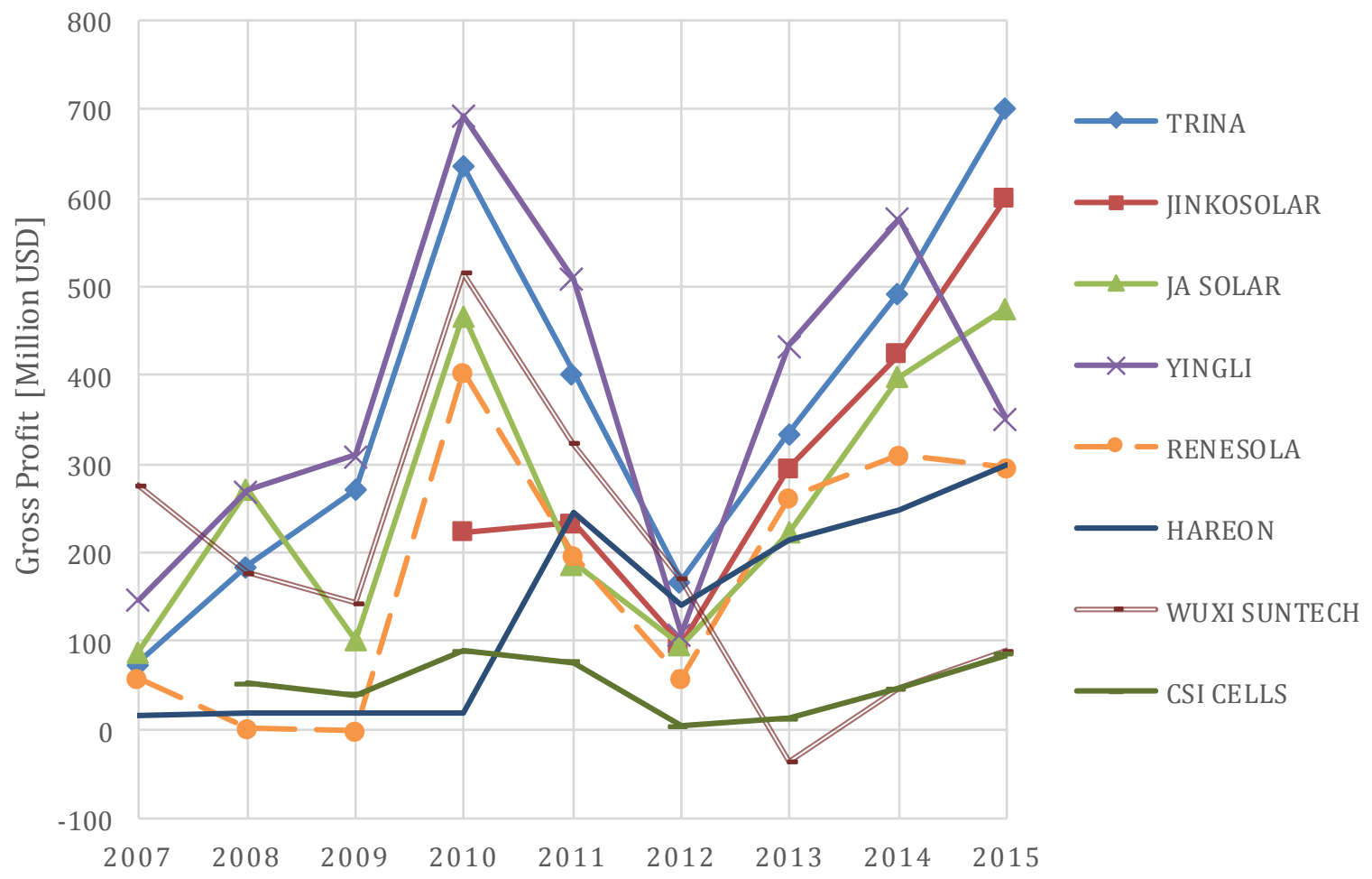

Data Source: Bureau van Dijk - Orbis da tabase (version 129.00). Author's own ela boration. 
Figure 4.5a shows the trend of firms' turnover as a two-year moving average during 2007-2015. Despite the general ascending trend, a clear turning point in 2011 can be noticed for the cellmanufacturing firms. With the only exception of SunTech, the Chinese cell-manufacturers were able to start recovering in 2013. SunTech reached a historical peak of $\$ 3.5$ billion in 2011 , then experienced a sharp decline into the level of \$500 million in 2014 (seven times less). On the other hand, the revenue of feedstock producers (GCL and LDK) was always growing. The turnover of GCL and LDK in 2015 was around $\$ 4.8$ and $\$ 3.5$ billion respectively.

Observing the gross profit (figure 4.5b), the image becomes even clearer. The solar PV industry in China entered a down cycle in the first quarter of 2011 until the end of 2012 then it recovered rapidly. The downturn reached its worst case in 2012, with companies registering very low profits. This sharp collapse of profits was common among all cell manufacturers in China. The gross profits declined from levels of $\$ 400-\$ 700$ million in 2010 into lower than $\$ 150$ million in 2012. SunTech experienced large losses of $\$ 36$ million in 2013. However, the analysis shows a rapid recovery of the industry, Trina, JinkoSolar, and JaSolar experienced high profits in 2015.

\section{International Involvement}

To test whether China serves as an offshore platform for PV production, we consider the FDI and M\&A activities in the field. First, if China's PV cell manufacturing is a consequence of other countries technologies, we expect high inward flows of FDI to Chinese subsidiaries of foreign firms. To check this hypothesis, we analysed the available data on foreign subsidiaries and M\&A actions taken by the traditional leaders in cell and feedstock production as well as the international firms with high patenting activities in China (Table B in appendix). 11 of the 18 deals took place in the period before 2007. Moreover, 15 of the 18 were joint-ventures with Chinese firms. This result not only confirms the well-known regulatory issues on FDI in China that still favour joint-ventures over pure subsidiaries, but also gives an indicator about the direction of technological capabilities transfer during that period.

Starting in 2000, a joint-venture by the German chemicals company BASF with a group of Chinese petrochemical producers in Shanghai Chemical Industry Park was announced. Later in 2003, BASF established another joint-venture company to produce crude Methylene diphenyl diisocyanate (MDI) ${ }^{15}$. In 2002, the American company DuPont ${ }^{16}$ announced via its main unit in China an agreement with a Japanese producer to set up production venture for copolymer acetal resins ${ }^{17}$. In 2003, Kyocera (Japanese) announced a joint-venture to import fine ceramics and electronic components, and another one to produce solar panels in China. In 2004, a jointventure between Samsung Electronics (Korean), Haier Group (Chinese), and Sanyo Electric (Japanese) was formed in Shanghai to operate maintenance and development services for electrical appliances.

\footnotetext{
${ }^{15}$ Among its other industrial a pplications, MDI is widely used for producing rigid polyurethane for solar panel encapsulation, and can be also used for the manufacturing of Dye-sensitized solar cells.

${ }^{16}$ DuPont is one of the top patent applicants for Chinese inventions in solar-cell common elements and panel encapsulation materials with 10 transnational patent applications.

${ }^{17}$ Copolymer a cetal resins can be used, a mong their several a pplications, for $\mathrm{PV}$ panel encapsulation.
} 
The Taiwanese company, AU Optronics ${ }^{18}$ entered the Chinese market in 2006 with a jointventure to produce backlight modules. Mitsubishi Electric (Japanese) established joint-ventures with Chinese companies to produce electric switches, inverters, and equipment in 2006-2013. Other leading firms such as Honeywell (American) and Shin-Etsu Chemical (Japanese) also established joint-ventures with Chinese firms in 2010-2011.

On the other hand, to test whether China had obtained its technological capabilities in the PV field through international involvement by outsourcing and acquiring foreign firms, we analyse the M\&A deals made by Chinese manufacturers (Table $\mathrm{C}$ in appendix). 14 of the 17 deals took place after 2007 . Most of them $(82 \%)$ were in form of acquisition of ass ets and business of foreign firms.

In 2006 and 2008, SunTech was very active in acquiring foreign firms. It started with acquiring the Japanese company, MSK Corporation (one of the top-ranking companies in buildingintegrated-PV). Later, SunTech acquired German and American firms, and formed a jointventure in the USA to finance PV projects.

In 2008, GCL-Poly acquired the British Virgin Islands based company, Joint Loyal Holdings to get shares in Duolun Golden Concord (DGC). DGC owns a coalmine under construction in Inner Mongolia, with a design output capacity of $1.2 \mathrm{Mtpa}$. The indirect acquisition provided GCL-Poly with a steady source of coal supply for its purification process of polysilicon. The second feedstock company, LDK was also active in M\&A activities during 2009-2011. It established a joint-venture with the German (back then ${ }^{19}$ ) cell manufacturer Q-Cells in 2009 and acquired high shares in Italian and American firms.

The Chinese companies JaSolar, Huawei, Aiko Solar, Hareon, and Hisense Electric, completely acquired foreign firms and subsidiaries located in the British Virgin Islands, the UK, Germany, and Mexico during 2011-2015. Through its activities to accumulate technological capabilities for power grid infrastructure, State Grid Corporation of China acquired seven high-voltage electricity transmission assets in Brazil in 2012, and established a joint-venture with a Russian power company in 2014.

\subsection{The Innovation Side}

The third analytical dimension to consider is the innovation side of the system. We review the licensing activities by Chinese actors to access foreign IPR, the R\&D expenses by main Chinese manufacturers, and their patenting activities.

\subsubsection{Net Charges for the use of intellectual property (NCIP)}

To further test whether China obtained its technological capabilities in PV through international involvement, we check the volume of licensing activities by Chinese residents to use IPR of foreigner innovators. The indicator NCIP is used to compare China with the USA, Germany, Japan, and Korea over 1995-2015 (Figure 4.7). While USA has a huge positive NCIP (around $\$ 90$ billion during the last five years), Korea and China have negative net charges indicating

\footnotetext{
${ }^{18} \mathrm{Au}$ Optronics was the top patent applicant for Chinese inventions in PV cells and panels with 45 transnational patent applications during 2010-2014.

${ }^{19}$ The Korean conglomerate company, Hanwha Group totally a cquired the German company Q-Cells in 2012.
} 
more payments than receipts. On the other hand, Japan and Germany are considered as main suppliers of IPs globally with \$20 billion and \$5 billion NCIP in 2015 respectively.

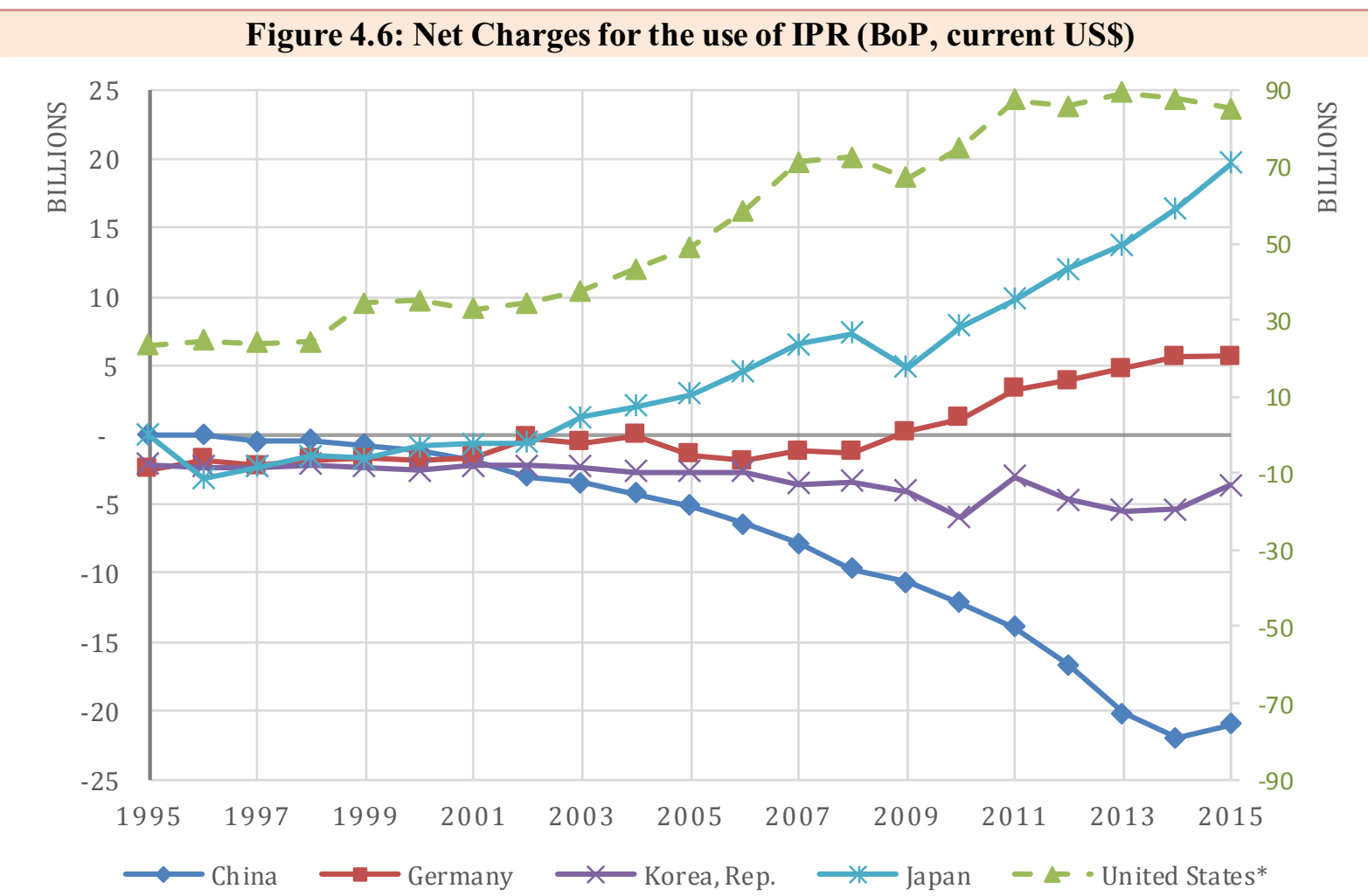

*Figures for United States are given in secondary axis. Data source: The World Bank, World Development Indicators Da tabase. Accessed in February 2017. Author's own elaboration.

Considering NCIP for China as a general indicator aggregated for all industries, total payments have increased dramatically since 2001 . This shows a large growth in licensing agreements signed by Chinese firms for the authorized use of IPRs (such as patents, designs, copyrights, and trademarks) owned by international parties. However, in the clean energy sector, licensing is not considered as the main channel for technology transfer. Karachalios et al $(2010$, p.58) found that only $17 \%$ of surveyed international leading organisations in the sector have frequently or occasionally entered into licensing agreements. In the case of PV technology in China, licensing has played no significant role in cell and panel producers, where in -house R\&D activities were more common (de la Tour, et al., 2011; Lema \& Lema, 2012). However, Zhao, et al. (2011, p.4966) noted high tendency of Chinese manufacturers to purchase Si-purification technology licenses from overseas.

\subsubsection{Companies' R\&D Expenses}

The second indicator to consider within the innovation side of the system is the R\&D activities done by the main Chinese actors (Figure 4.7). Starting from less than $\$ 2.5$ million in 2007, the R\&D expenses increased by all firms until 2011. After that, they took three different trends. Some companies continue their R\&D growth (either with similar rate e.g. JinkoSolar and JaSolar, or with even a higher speed e.g. Yingli, Hareon, and GCL). Other companies reduced their expenditure on research, e.g. Trina and SunTech (In the case of SunTech, although it has the highest R\&D expenditures before 2011, the company shut down its R\&D units since 2013). The third trend is noticed in the case of Renesola, where the $R \& D$ expenses reached a stagnation 
level of $\$ 45$ million since 2011. Yingli is the Chinese leader in R\&D since 2014, with more than $\$ 73$ million spent in 2015 .

\section{Figure 4.7: R\&D Expenses of Chinese PV Firms 2007-2015}

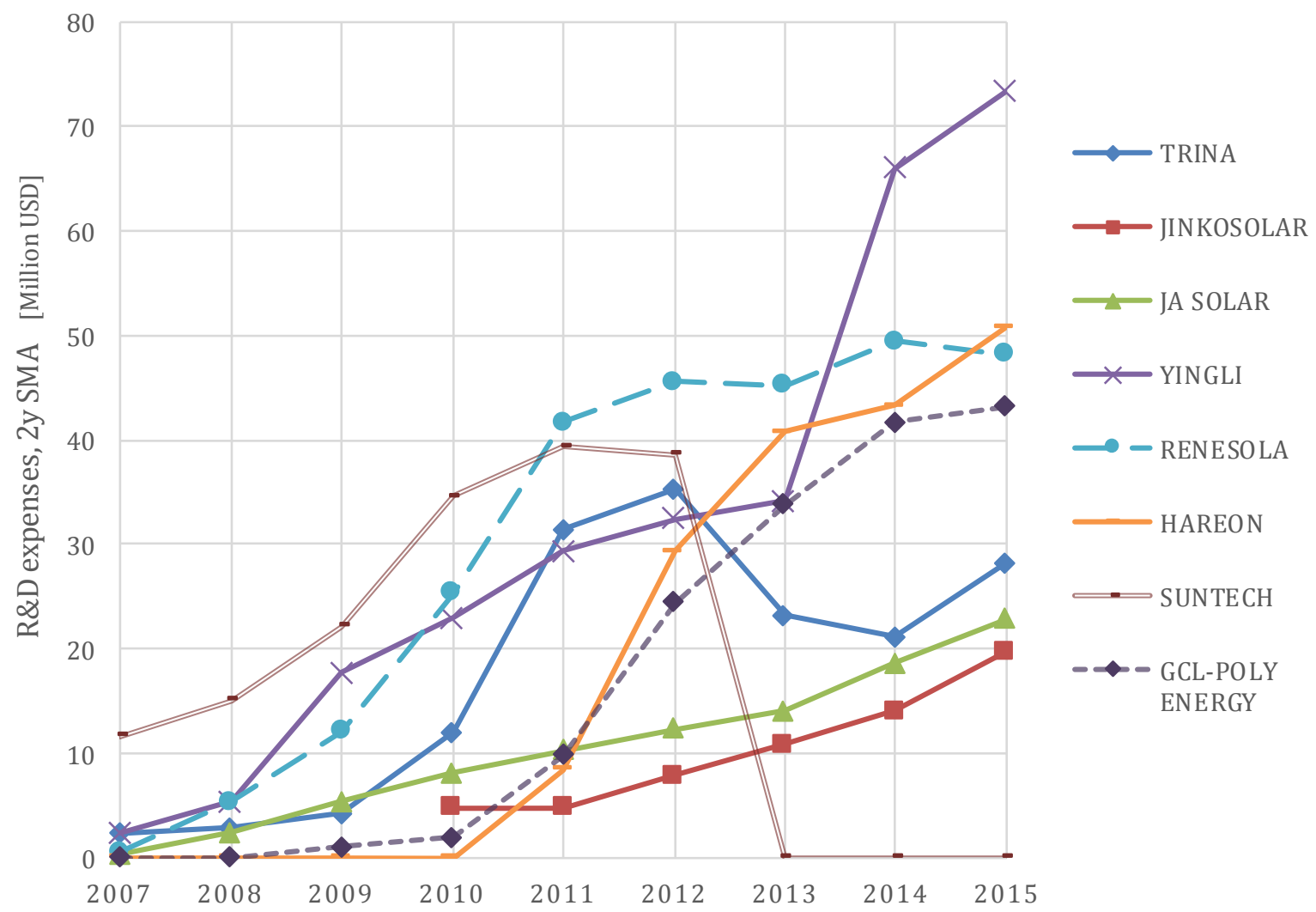

Data Source: Bureau van Dijk - Orbis da tabase (version 129.00). Author's own elaboration.

\subsubsection{Patenting Activities}

\section{Priority Patent Filings}

Regarding innovation throughput, the first indicator we consider is the patent priority filings (defined in section 3.3). As illustrated in Figure 4.8a, China experienced a notable growth in priority filings since 2005 . Within few years, the country was able to introduce and accumulate a large stock of patents protected by its national patent office. Starting from a very late position behind Japan, Korea, USA, Germany and Taiwan, and having an average of 9 filings per year during 1995-1999, Chinese annual patents exceeded Germany, USA and Taiwan in 2005 with 245 annual patents, and later went beyond Korea in 2010. Of note, the Chinese activities were further able to surpass the traditional leader in PV priority patents, Japan, in 2011.

In terms of the accumulated number of priority filings since the earliest PV patent applications were filed in USA and Germany in the 1950s until 2012, China occupies the third place with a share of $12 \%$, following Japan (53\%) and South Korea (14\%). The final remark in this regard is the fact that only $0.5 \%$ of the Chinese priority patents in the field have already expired by 2012 , comparing to the Japanese case, where around $37 \%$ of the total priority patents have expired. Table D (in appendix) shows the top firm and non-firm applicants for priority patents with at least one inventor located in China during 1995-2014. 
Figure 4.8: Patenting Activities of Top Inventor Countries (1995-2011)

a) Priority Filings

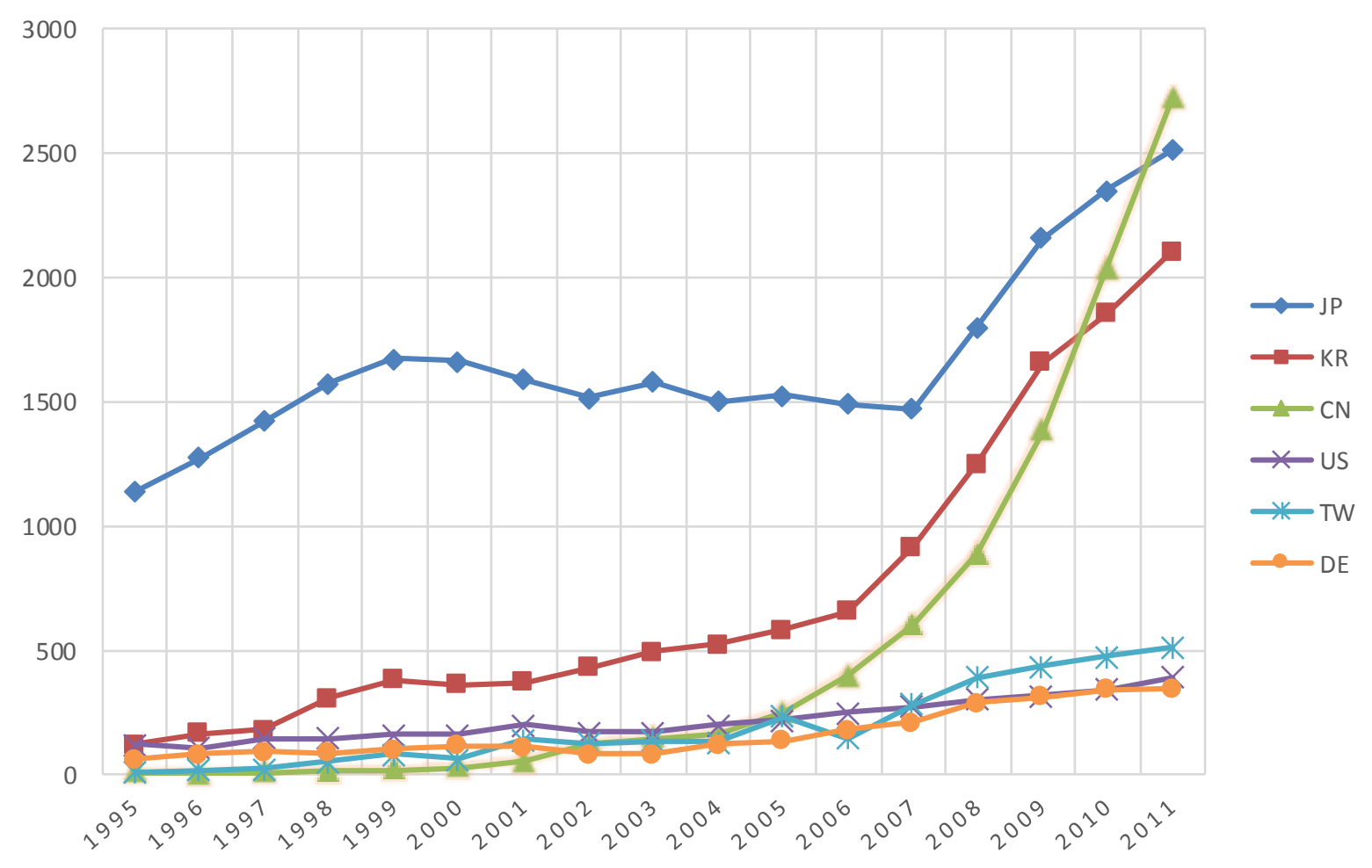

\section{b) Transnational Patent Applications}

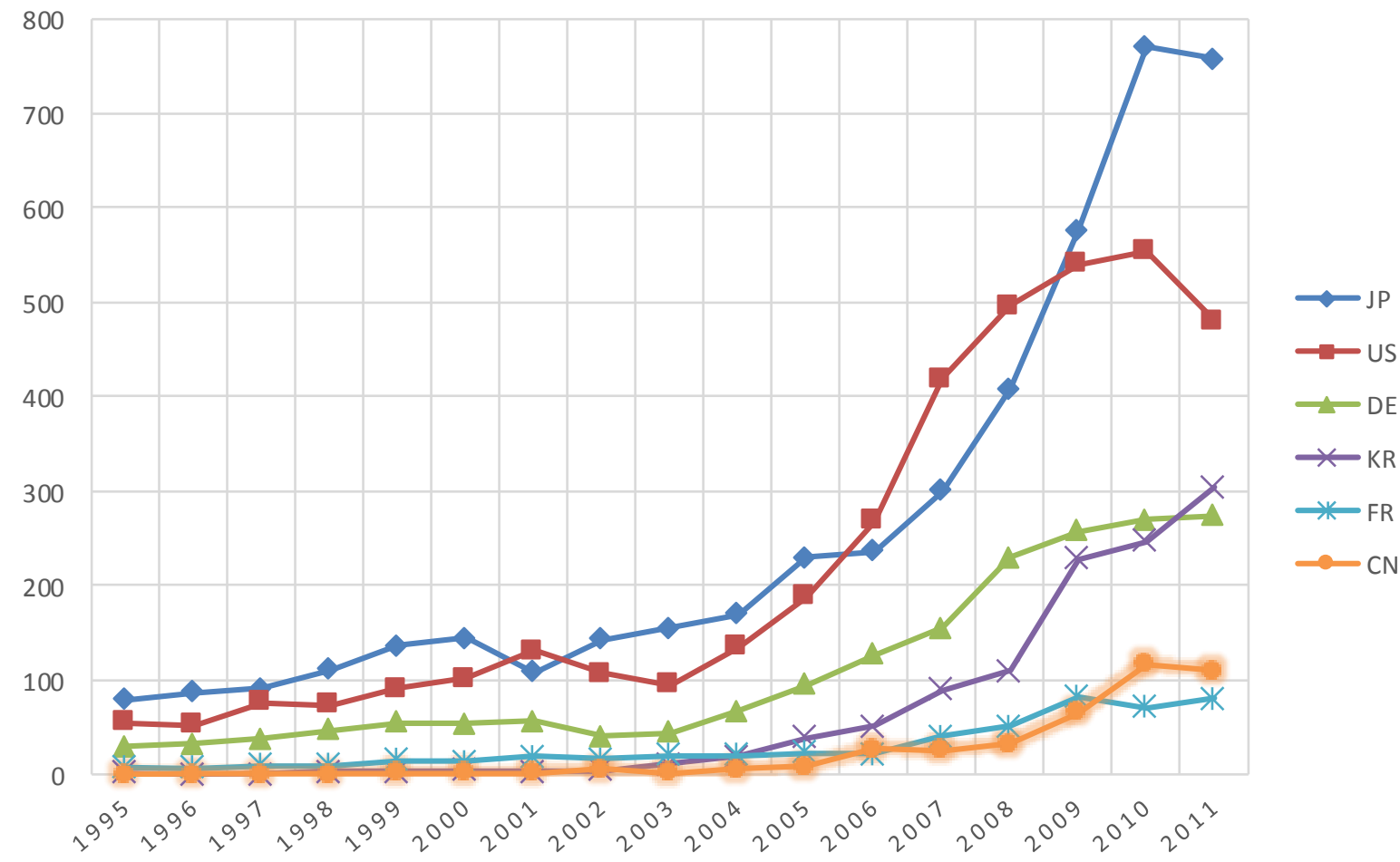

Source: PATSTAT 2015. Author's own elaboration. 


\section{$\underline{\text { Transnational Patent Applications }}$}

Unlike its performance in priority filings, China has a less significant presence in the transnational patent landscape. The trends in Figure $4.8 \mathrm{~b}$ shows that China occupies the sixth place in accumulated transnational patent applications in the PV field, after Japan, USA, Germany, Korea, and France respectively. Chinese inventors were involved in only 3\% of the total accumulated number of transnational patents during the period 1977-2012. Moreover, China has successfully exceeded France in terms of annual patent counts in the past five years. Starting from a very low level of PV transnational patents in the late nineties, Chinese patent activities have dramatically increased since 2008 . Only $0.03 \%$ of the Chinese transnational patents in the field have already expired by 2012 , compared to $8 \%$ of the Japanese and $11 \%$ of the American and German patents.

\section{Technological Specialization of Chinese PVInventions}

To have a better understanding of the PV inventive activities undertaken in China, we further analyse the technological specialization of its transnational patents over time. Figure 4.9 shows the relative specialization on the level of main PV groups. During the first period, the largest share was associated with portable devices. This can be seen from the absolute share (53\%) within the Chinese patents, as well as from the very high sRTA (0.95). However, the analysis shows that both the absolute and relative advantage in the devices field dramatically decreased over the next periods, where panels and cells gained notable scores. In the fourth period, both panel and cell technologies continue to have dominant shares, however, an emerging stream of electronic inventions can be noticed. Although, the absolute share of storage patents is low, it had high sRTA in the second and third periods.

Since cell technologies hold the highest share of patents in the Chinese TIS, we investigate the specialization of their patents to the next level, considering the different cell families along with the Silicon purification methods for producing feedstock. A sharply decreasing RTA for thinfilm and multi-junction cell technologies indicates low specialization in them. On the other hand, a high specialization in the $1 \mathrm{G}$ technologies is notable since the third period with $46 \%$ share and 0.2 sRTA. Furthermore, the analysis shows a steady positive advantage in the polysilicon feedstock technologies over the last three periods. 
Figure 4.9: China's Relative Specialization in PV System Technological Groups

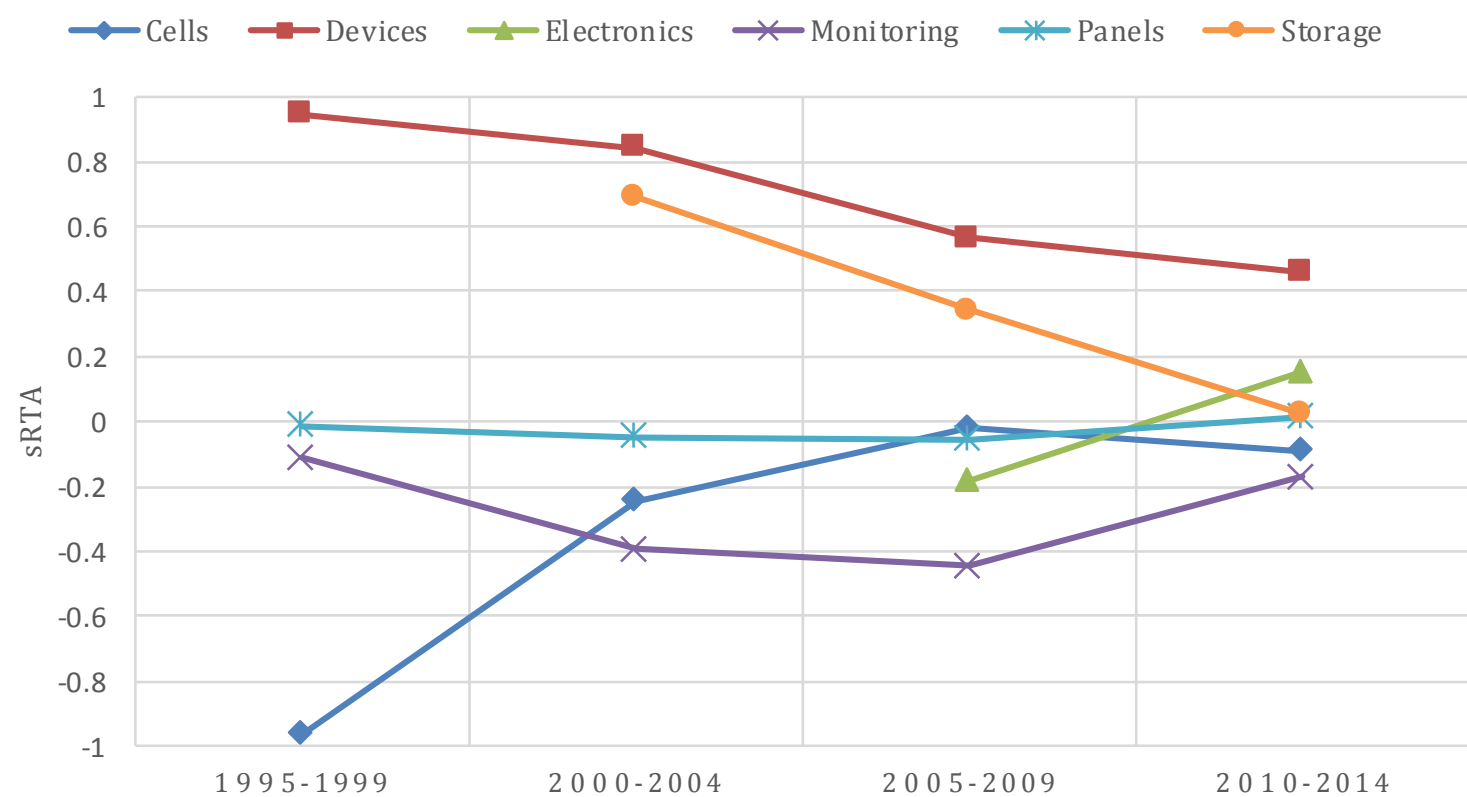

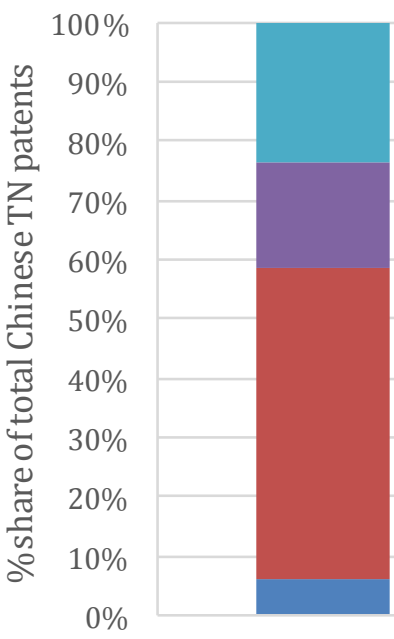

1995-1999

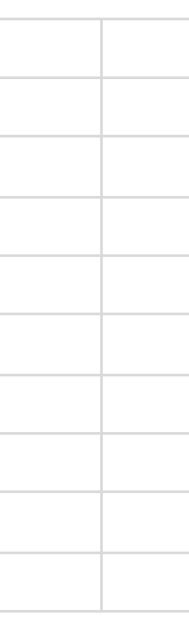

$2000-2004$

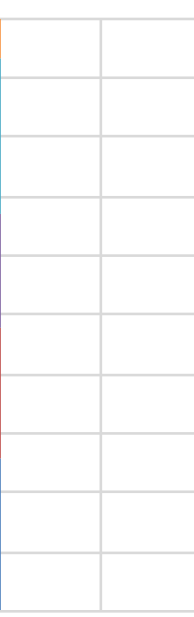

2005-2009

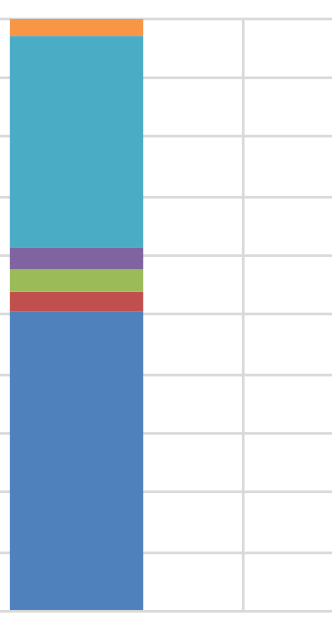

- Cells Devices $\quad$ Electronics $\quad$ Monitoring $\quad$ Panels $\quad$ Storage

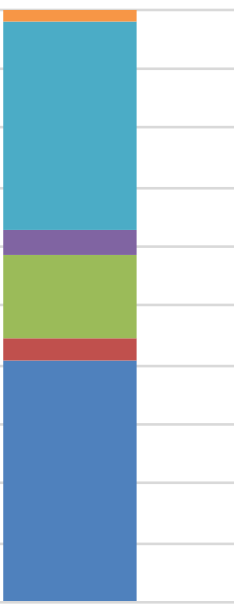

2010-2014 


\section{DISCUSSION}

\subsection{The Complete Image}

According to the results, the development of the Chinese PV technological system of production and innovation went through four main consecutive periods (figure 5.1).

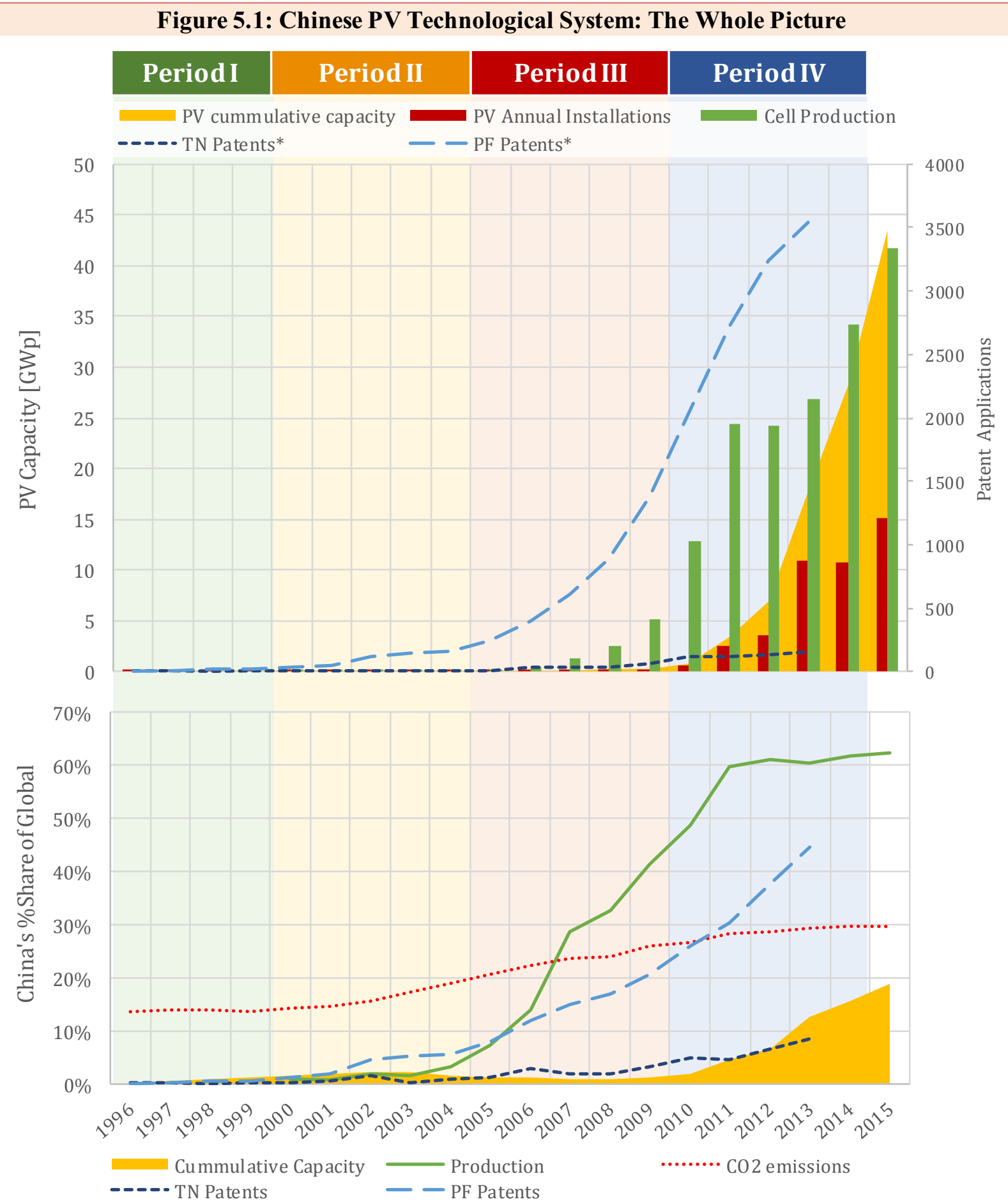

* The figures of priority filings (PF) and transnational patents (TN) are given in a secondary axis in the upper graph.

Data Sources: PV installed capacity data: BP Statistical Review of World Energy 2016. PV cell production data: Dataset of (Brown, et al., 2015). Patent data: PATSTAT database 2015, autumn edition. CO2 emissions data: Emission Database for Global Atmospheric Research (EDGAR), release version 4.3.2., European Commission, Joint Research Centre (JRC)/PBL Netherlands Environmental Assessment Agency.

Author's own elaboration. 


\section{Period I (1995-1999): 'Seed Germination’}

In this period, Chinese government plans and policies were focused on two main aims. First to build a knowledge base for science and technology, and second, to achieve wider coverage in rural electrification. This government attitude was accompanied with innovation activities for developing portable devices powered by solar PV energy. The inventive activities in this period were individual and appear to have been driven by foreigner firm actors and universities.

In the global PV cell and panel market, China's position was relatively small compared to the dominance of American and Japanese manufacturers. However, a clear tendency towards developing domestic grounds for basic research can be noted.

\section{Period II (2000-2004): 'Vegetative Stage'}

In the second period, the government plans became more focused in supporting the establishment of domestic solar panel industry by facilitating the acquiring of manufacturing equipment and supporting R\&D activities. Consequently, several PV companies were bom either by the end of the first period or in this period, such as Trina, Yingli, Tbea Xinjiang Sunoasis, Hareon Solar, and Wuxi Suntech. Furthermore, an increasing international involvement within the Chinese production and innovation system is also noticed through FDI and joint-ventures for production of chemical materials used in PV systems. Subsidiaries of some of the main international leaders in the PV field were also established in China during this period. The inventiveness activities within the country increased especially in terms of priority patents. The technological specialization of patents was focused on portable devices and PV panels.

On the international market side, in this period, China still had no significant role in both production and installations, which were dominated by Japan, USA, and Europe. Since 2004, the fast growing market for PV panels in Germany became the largest market in the world, and thus the favoured destination of the emerging Chinese panel production.

\section{Period III (2005-2009): 'Flowering'}

The success of panel production in the second period and the expansion of international demand on PV systems stimulate a further growth in PV industry in China. Government policies were generously supportive of this growth through several laws, subsidies, and initiatives. The trend toward export-oriented industry was clear in both government policies and firms' performance. Consequently, additional PV companies entered the industry, which expanded vertically to include solar cell production. Most of the Chinese stars were born in this period, such as JaSolar, Jinkosolar, and Renesola. Moreover, additional foreign subsidiaries were established in China to produce PV cells and modules, such as the Taiwanese AU Optronics (Xiamen) and the Canadian CSI-Cells. Consequently, technological specialization of patenting activities notably shifted towards c-Si solar cells. Despite the fact that most silicon feedstock supply for Chinese PV factories was imported from international markets, two Chinese firms (GCL and LDK) entered the market and started building technological capabilities in that field. Both transnational and priority patent applications for Chinese PV inventions experienced dramatic take-off since 2007. This year (2007) was also a turning point in the international involvement direction, since when Chinese firms started to acquire international companies. 
The PV business in China experienced a dramatic growth both in its size (number of jobs) and performance (turnover). The prosperous industry became a labour market for more than 1.5 million employees. Most of the PV production was exported to international markets, where Germany had the largest demand. Having the advantages of lower labour cost, high government subsidies, and less strict environment protection laws, the prices of Chinese PV cells and panels were difficult to compete by international industries.

In this period, the main Chinese PV firms registered their holding companies in Cayman Islands and British Virgin Islands, which served as both tax haven and listing vehicles to undertake Initial Public Offerings (IPO) on NYSE and NASDAQ stock exchanges in the USA. Consequently, the firms raised estimated gross IPO proceeds of more than $\$ 1$ billion (Binz \& Anadon, 2016). Furthermore, the IPO dramatically improved their access to short-term bank borrowing. Being driven by the fast growing European market, Suntech Power, for example, took more than $\$ 600$ million short- and long-term loans from several Chinese and international banks following its IPO in 2005, which allowed it to dramatically expand its production capacity, undertake series of international acquisitions, and become the global leader.

By 2009 , China was accountable for $40 \%$ of the global PV production, $20 \%$ of priority patents, and only $3 \%$ of transnational patents. Interestingly, the growth trend of priority patents has become significantly larger than that of transnational patents. It was rather consistent with the production share trends. This observation indicates a strong competition between the global PV actors taking place in the Chinese market. In the light of the supportive circumstances in China for PV industry, it became difficult for international companies to carry on with a competitive industry outside China. This apparently led to defensive patenting strategies by the traditional leaders, who continue to file transnational patent applications. On the other hand, working under the same supportive circumstances, the differentiation between Chinese manufacturers became restricted in two aspects. First, to gain a larger market share, PV companies in China needed to obtain capabilities for producing more efficient cells, improve their manufacturing processes, or use materials of less cost. Second, such innovations were either achieved internally (and thus protected with domestic patent filings) or obtained via outsourcing activities like licencing and acquisition. In other words, with priority filings, companies aimed at protecting their incremental innovations in order to maintain their competitiven ess in the local market, as well as to obtain more government subsidies.

Although PV systems are considered a clean energy source, they were not environmentally beneficial in China in this period because of the export-oriented strategy. Alsema \& de WildScholten (2006) noted that the life-cycle $\mathrm{CO}_{2}$ emissions of c-Si PV systems are $40 \mathrm{~g} / \mathrm{kWh}$ on average, comparing to $1000 \mathrm{~g} / \mathrm{kWh}$ in the case of using hard coal for electricity generation. Analysing the market dynamics with one-year lag between production and installation, our results show that only $7.8 \%$ of the Chinese PV production were used domestically. Using coal

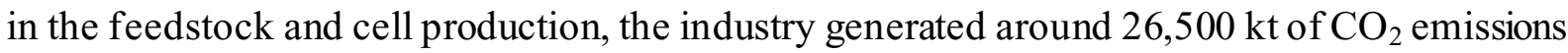
$(0.07 \%$ of the total emissions in China in this period). Our calculations show that $8,260 \mathrm{kt}$ of $\mathrm{CO}_{2}$ were saved because of PV installations in the period, which results in net $\mathrm{CO}_{2}$ emissions of 18,240 kt caused by the PV industry (negative savings). Thus, the PV industry has posed an additional burden on the air pollution problems in China in this period. 


\section{Period IV (2010-2014): 'Getting Back to Roots'}

By the beginning of the fourth period, the Chinese PV production system faced severe external shocks. A sharp recession in the global demand due to institutional alterations in the German market in 2010, followed by AD and CVD tariffs on Chinese PV products enforced in both USA and EU. Chinese PV manufacturers, who were already running on their full capacity, faced difficult situation in 2011 and 2012 with huge financial loses that even led to bankruptcy of some important actors, such as SunTech in 2013 being defaulted on \$541 million of convertible bonds.

To rescue the huge PV industry with its large labour market and assets, a comprehensive set of policies were introduced by the Chinese government mainly to stimulate the domestic market. The government intervention, despite the complexities underlying the formulation of industrial policies, was highly beneficial from socio-economic and innovative perspectives. On one hand, it rescued the companies and their employees and increased the share of renewable sources in energy production, and on the other, it maintained the growth of $R \& D$ and patenting activities.

In this period, around $35 \%$ of the Chinese PV production was installed domestically. Although the industry generated around $346,000 \mathrm{kt}$ of $\mathrm{CO}_{2}$ emissions $(0.7 \%$ of total emissions in China), the domestic PV installations in this period saved around $482,000 \mathrm{kt}$ of $\mathrm{CO}_{2}$, yielding positive net $\mathrm{CO}_{2}$ savings of $136,000 \mathrm{kt}$, and making the industry environmentally efficient.

On the innovation side, the government intervention indirectly resulted in three positive effects. First, it stimulated learning processes in the system, as illustrated by the performance of Chinese feedstock firms. Such high-tech manufacturing processes formed a hurdle for the Chinese firms in the initial stages. They used to buy polysilicon ingots and wafers from the inte rnational market mainly dominated by Japanese, German and American firms. However, with the preservation of the Chinese PV system (as well as the Chinese AD duties on polysilicon imports), some domestic companies succeeded in accumulating technological cap abilities and were able to enter the polysilicon global market achieving high shares since 2010. Second, the rescue of R\&D activities in cell manufacturers led to the achievement of a global cell efficiency record in multi-crystalline cells by Trina beginning in 2014. Third, it opened up new fields of specialization and development, which are the PV electronics and inverter technologies, as the Chinese state grid companies needed to develop the grid infrastructure to cope with the growing utilisation of solar electricity.

The interrelations between the analytical dimensions of the PV technological system of production and innovation in China are summarized in figure 3.1 and table 5.1. While the institutions, market, and innovation are completely interrelated, the results show different pattern for environment. Direct influence of environmental aspects was found neither on market nor on innovation. Environment influenced them indirectly through institutions. Similarly, we could not find a direct influence of institutions on environment, its influence nonetheless occurs indirectly via the market dynamics or innovation. 
Table 5.1: The interrelations between the analytical dimensions of the PV TIS in China

\begin{tabular}{|c|c|c|c|}
\hline \multirow{2}{*}{$\begin{array}{c}\text { Source } \\
\text { (influencing) }\end{array}$} & \multirow{2}{*}{$\begin{array}{l}\text { Destination } \\
\text { (influenced) }\end{array}$} & \multicolumn{2}{|c|}{ Influence } \\
\hline & & Positive + & Negative - \\
\hline \multirow[t]{2}{*}{ Institutions } & Market & $\begin{array}{l}\text { - Supportive government policies } \\
\text { (supply push and regulations) } \\
\text { - Demand pull policies stimulated } \\
\text { domestic market }\end{array}$ & - External shocks \\
\hline & Innovation & $\begin{array}{l}\text { - Scientific collaboration programs } \\
\text { - Supporting R\&D and IPR } \\
\text { - Attracting overseas experts (e.g. } \\
\text { thousand talents plan) }\end{array}$ & \\
\hline \multirow[t]{3}{*}{ Market } & Institutions & $\begin{array}{l}\text { - Industrial success caused more } \\
\text { supportive policies } \\
\text { - The down-cycle triggered the } \\
\text { stimulation of domestic market } \\
\text { (FIT and energy conversion laws) }\end{array}$ & $\begin{array}{l}\text { - Global competition caused } \\
\text { external shocks (e.g. AD and } \\
\text { CVD) }\end{array}$ \\
\hline & Innovation & $\begin{array}{l}\text { - Industrial success stimulated } \\
\text { R\&D and provided financial } \\
\text { support for patenting } \\
\text { - M\&A deals provide access to } \\
\text { foreign IPR } \\
\text { - The emergence of domestic } \\
\text { market horizontally expands the } \\
\text { patent portfolio of China (e.g. } \\
\text { electronic inverters) }\end{array}$ & $\begin{array}{l}\text { The down-cycle reduced R\&D of } \\
\text { some companies (e.g. Suntech } \\
\text { and Trina) }\end{array}$ \\
\hline & Environment & - Installations reduce $\mathrm{CO}_{2}$ emission & - Production emits $\mathrm{CO}_{2}$ \\
\hline \multirow[t]{3}{*}{ Innovation } & Institutions & $\begin{array}{l}\text { - Success stories (e.g. Suntech's } \\
\text { founder) inspired policy (e.g. } \\
\text { thousand talents plan) }\end{array}$ & \\
\hline & Market & $\begin{array}{l}\text { Inventiveness, R\&D, licensing } \\
\text { foster firm competiveness }\end{array}$ & $\begin{array}{l}\text { - Patents by incumbent leaders } \\
\text { impede catch-up by latecomers }\end{array}$ \\
\hline & Environment & - Increasing cell efficiencies & \\
\hline Environment & Institutions & - Climate change, air quality proble & is trigger remedial policies \\
\hline
\end{tabular}

Author's own ela boration.

\subsection{China's PV Catching-up Trajectory}

Tracking the Chinese development in the PV industry using the catch-up cycles framework introduced by (Lee \& Malerba, 2017), the results show that China's 'entry' to the global market occurred over 1998-2005. During 2006-2008, it experienced 'gradual catch-up' processes. In 2008, the country entered the 'forging ahead' stage with 'persistency of leadership' until present. The analysis further shows that the shift in industrial leadership towards China was mainly driven by institutional and demand 'windows of opportunity'. While the demand played an important role in triggering the catch-up, a public policy window was opened through the government intervention in the midst of the global economic and institutional challenges. The responses of different actors within the sectoral system to the radical discontinuities were instrumental in the catch-up process. Chinese firms successfully took the advantage of the windows of opportunity to forge ahead.

From a technical perspective, the catch-up process in the Chinese case followed a specific trajectory (devices, panels, cells, wafers, polysilicon, and finally electronics). It started with the development of portable lighting devices powered by imported solar cells. It then switched to the assembly of PV panels also based on imported cells from overseas. On the following stage, 
a domestic cell and wafer industry emerged through acquiring foreign manufacturing equipment, however, it had been dependent on imports of polysilicon from USA, Europe and Japan. Gradually, the domestic industry accumulated technological capabilities and became able to produce polysilicon ingots. Finally, due to the institutionally driven growth of domestic market, further capabilities started to be accumulated in electrical inverter technologies.

Although this trajectory seems to be similar to the catch-up process in pharmaceuticals and software industry in India and in the Taiwanese and Malaysian semiconductor firms (Malerba $\&$ Nelson, 2011), one key difference in the Chinese PV case is that technological capabilities in different components of the technical system were accumulated by different firms.

On the other hand, similar to the successful catch-up cases discussed by (Malerba $\&$ Nelson, 2011; Mowery \& Nelson, 2001), our analysis highlights the importance of learning processes, access to foreign knowledge, skilled human capital, and active government policy in the PV case in China.

\section{$5.3 \underline{\text { Implications and Lessons }}$}

The present case study suggests several implications for China, other emerging and developing economies as well as for developed countries.

In what concerns China, the fast government intervention with supportive policies and subsidies show successful effect in the PV case especially with the stimulation of domestic market. However, to maintain the industrial leadership, Chinese firms should find new markets for utility-scale PV outside China. Two possible candidates could be oil-producing countries in the Middle-East and Africa (given their favourable conditions of solar irradiation and the depletion of oil reserves in the long-term), as well as other emerging economies such as India and Brazil (given their need to stable sources of energy).

As to emerging and developing countries, the Chinese PV case highlights the significant role of public policy in supporting the industry through its development stages. Furthermore, it sheds light on the importance of knowledge transfer through scientific cooperation and the mobility of skilled personnel. Such channels can pave the way for emerging states to accumulate domestic capabilities towards catching-up with forerunners.

In what concerns developed countries and incumbent leaders, the analysis shows the ineffectiveness of punitive policies in enhancing competitiveness nor in supporting domestic industry. Instead of protecting the local industry as intended, the imposed duties on Chinese PV products raised the prices of solar panels in the western markets hindering the adoption rate of the green technology therein. More efficient alternatives in that regard could have been achieved by incumbent leader governments through directly subsidizing their local firms, or by the firms themselves through offshoring their production activities to China maintaining local panel assembly and encapsulation plants. Either way, in such vital sector related to the global challenge of climate change, collaboration would be more useful than trade wars.

\section{CONCLUSION}

This study analysed the Chinese technological system of production and innovation in the field of solar photovoltaics. Following the systematic approach of the TIS, the paper highlighted the main factors that influenced the production and innovation processes. It inspected the system 
development from three analytical dimensions: the institutional framework of the system, its market dynamics, and the composition of innovative activities of the main actors. The results show a significant role of government policy instruments in developing indigen ous capabilities within the system and rescuing it in the tough situations.

On market level, China has become the world's leader of PV installations since 2015. Likewise, its global market share boosted to around $60 \%$ in 2013. This rapid growth can be partially connected with export-oriented policies and the involvement of international actors during 2005-2009. Despite the negative environmental effect of the PV industry in the initial stages (due to the heavily export-oriented strategy), the stimulation of domestic market resulted in effective $\mathrm{CO}_{2}$ reduction in the last stage.

The patent analysis shows that in spite of their puzzling low activities in transnational patents, the Chinese actors have a notable performance in terms of priority filings. This observation illustrates an interesting role for patents as a market instrument used by leading actors in highincome countries to compensate their potential losses of market shares due to low labour costs in emerging economies.

The results also show that the Chinese system is not isolated from the global technological system of production and innovation in the field. The interactions and events occurring within the global system cast a shadow on the Chinese system dynamics. At some stage, they motivated production processes to very high levels. At other stages, they formed external shocks that caused industry enter down-cycle and resulted in structural change. Interestingly, thanks to successful government intervention, both positive and negative externalities have stimulated, in one way or another, the capability building and innovation activities in China.

\section{ACKNOWLEDGEMENTS}

The author is immensely thankful to Judyta Lubacha-Sember for her assistance with the literature review and the references list. The author is also very grateful to Johan Schot, W. Edward Steinmueller, and two anonymous reviewers for their valuable comments on an earlier version of the manuscript.

\section{REFERENCES}

Alsema, E. A. \& de Wild-Scholten, M. J., 2006. Environmental Impacts of Crystalline Silicon Photovoltaic Module Production. Leuven, 13th CIRP International Conference on Life Cycle Engineering.

Archibugi, D., 1992. Patenting as a n indicator of technological innovation: a review. Science and Public Policy 19(6), 357-368. doi: 10.1093/spp/19.6.357

Baker, L., Sovacool, B., 2017. The political economy of technological ca pabilities and global production networks in South Africa's wind and solar photovoltaic (PV) industries. Political Geography 60, 1-12.

Ba lassa, B., 1965. Tra de liberalisation and "revealed" comparative a dvantage. The Manchester School 33(2), 99-123.doi: 10.1111/j.1467-9957.1965.tb00050.x

Ball, J., Reicher, D., Sun, X. \& Pollock, C., 2017. The New Solar System: China's Evolving Solar Industry and Its Implications for Competitive Solar Power in the United States and the World, Stanford, CA: Stanford Steyer-Taylor Center for Energy Policy and Finance.

Barell, R., Pa in, N. 1997. Foreign Direct Investment, Technological Change, and Economic Growth within Europe. The Economic Journal, 107(445), 1770-1786. Stable URL: http://www.jstor.org/stable/2957907

Binz, Ch., Tang, T., Huenteler, J., 2017. Spatial lifecycles of cleantech industries - The global development history of solar photovoltaics. Energy Policy 101,386-402. doi: 10.1016/j.enpol.2016.10.034 
Binz, Ch., Ana don, L.D., 2016. Transplanting clean-tech paths from elsewhere: The emergence of the Chinese solar PV industry. CIRCLELund University Papers in Innovation Studies Paperno. 2016/29 (downloaded on 10 January 2017 http://www.ike.aau.dk/digitalAssets/249/249115_201629_binz_path-transplantation.pdf).

Bla lock, G., Gertler, P.J., 2008. Welfare ga ins from Foreign Direct Investment through technology transfer to local suppliers. Journal of International Economics 74(2), 402-421. doi: 10.1016/j.jinteco.2007.05.011

Borras, S., Edquist, Ch., 2013. The choice of innovation policy instruments. Technological Forecasting \& Social Change 80(8), 1513-1522. doi: 10.1016/j.techfore.2013.03.002

Brown, L. R., Adams, E., Larsen, J., Roney, J. M., 2015. The Great Transition: Shifting from Fossil Fuels to Solar and Wind Energy. W. W. Norton \& Company, New York.

Cardwell, D., 2014. U.S. Imposes Steep Tariffs on Chinese Solar Panels. The New York Times, Volume December 17,2014,p. B2.

Carlsson, B., Stankiewicz, R., 1991. On the Nature, Function and Composition of Technological Systems. Journal of Evolutionary Economics 1(2), 93-1 18. doi: 10.1007/BF01224915

Ciftja, A., Engh, T. A. \& Tangstad, M., 2008. Refining and Recycling of Silicon: A Review. Trondheim, Norwegian University of Science and Technology. Permanent link: http://hdl.handle.net/11250/244462

Cooke, P., GomezUranga, M., Etxebarria, G., 1997. Regional innovation systems: Institutional and organizational dimensions. Research Policy 26(4-5), 475-491. doi: 10.1016/S0048-7333(97)00025-5

De la Tour, A., Gla chant, M., Meniere, Y., 2011. Innovation and international technology transfer: The case of the Chinese photovoltaic industry. Energy Policy 39(2), 761-770. doi: 10.1016/j.enpol.2010.10.050

De Rassenfosse, G., Dernis, H., Guellec, D., Picci, L., van Pottelsberghe dela Potterie, B., 2013. The worldwide count of priority patents: A new indica tor of inventive activity. Research Policy 42(3), 720 -737.

DominguezLa casa, I. \& Shubbak, M. H., 2016. Technological Knowledge Networks in China: The Case of PV Technology. Brighton, SPRU 50th Anniversary Conference - University of Sussex.

DominguezLa casa, I. \& Shubbak, M. H., 2018. Drifting towards innovation: The co-evolution of patent networks, policy, and institutions in China's solar photovoltaics industry. Energy Research \& Social Science, Volume 38,pp. 87-101.

Edquist, Ch., 1997. Systems of Innovation Approaches - Their Emergence a nd Characteristics. In Ch. Edquist (Ed.), Systems of Innovation. Technologies, Institutions and Orga nizations. Pinter, London a nd Washington, pp. 1-35.

Fischer, D. 2012. Challenges of low carbon technology diffusion: insights from shifts in China's photovoltaic industry development. Innovation a nd Development 2(1), 131-146. doi: 10.1080/2157930X.2012.667210

Flana gan, K., Uyarra, E., La ranja, M., 2011. Reconceptualising the 'policy mix' for innovation. Research Policy 40(5), 702-713. doi: 10.1016/j.respol.2011.02.005

Freeman, C., 1988. Japan: Anew National Innovation Systems? In: G. Dosi, C. Freeman, R.R. Nelson, G. Silverberg, L. Soete (Eds.), Technology and economic theory. Pinter Publishers, London, pp. 330-348.

Frietsch, R., Schmoch, U., 2010. Transnational Pa tents and International Markets. Scientometrics 82(1), 185200. doi: 10.1007/s11192-009-0082-2

Fu, L., Chen, X., Leutz, R., 2012. Natural Conditions and Administrative Settings For Concentrating Photovoltaics in China. AIP Conference Proceedings 1477(1),383-386. doi: 10.1063/1.4753910

Fu, X., 2015. Key Determinants of Technological Ca pabilities for a Green Economy in Emerging Economies. In: R. Vos \& D. Alarcon, eds. The United Nations Series on Development: Technology and Innovation for Susta inable Development. New York: Bloomsbury Academic, pp. 151-182

Gosens, J., Lu, Y., Coenen, L., 2015. The role of transnational dimensions in em erging economy 'Technological Innovation Systems' for clean-tech. Journal of Cleaner Production 86, 378-388.

Grau, T., Huo, M., Neuhoff, K., 2012. Survey of photovoltaic industry and policy in Germany and China. Energy Policy 51,20-37. doi: 10.1016/j.enpol.2012.03.082

Gründinger, W., 2015. What drives the Energiewende? New German Politics and the Influence of Interest Groups. PhD disserta tion. Humboldt-Universität zu Berlin. (downloaded on 25 February 2017 from http://www.wolfgang-gruendinger.de/what-drives-the-energiewende/). 
Gruss, L., ten Brink, T., (2016). The Development of the Chinese Photovoltaic Industry: an a dvancing role for the central state? Journal of Contemporary China 25(99), 453-466. doi: 10.1080/10670564.2015.1104914

Gul, M, Kotak, Y., Muneer, T. (2016). Review on recent trend of solar photovoltaic technology. Energy Exploration \& Exploitation, 34(4), 485-526. DOI: $10.1177 / 0144598716650552$

Hegedus, S. \& Luque, A., 2010. Achievements and Challenges of Solar Electricity from Photovoltaics. In: S. Hegedus \& A. Luque, eds. Handbook of Photovoltaic Science and Engineering. Chichester: John Wiley \& Sons, pp. 1-38.

Hoekman, B.M., Maskus, K.E., Sa ggi., K., 2005. Transfer of Technology to Developing Countries: Unila teral and Multila teral Policy Options. World Development 33(10), 1587-1602. doi: 10.1016/j.worlddev.2005.05.005

Hodgson, G.M., 2006. What Are Institutions? Journal of Economic Issues, 40(1), 1-25.

Honghang, S., Qiang, Z., Yibo, W., Qiang, Y., Jun, S., 2014. China’s solar photovoltaic industry development: The sta tus quo, problems and a pproaches. Applied Energy 118, 221-230.

Huang, P., Negro, S.O., Hekkert, M.P., Bi, K., 2016. How China became a lea der in solar PV: An innovation system analysis. Renewable and Sustainable Energy Reviews 64, 777-789. doi: 10.1016/j.rser.2016.06.061

Hubbard, S. M., Bailey, Ch., Polly, S., Cress, C., Andersen, J., Forbes, D., Raffaelle, R., 2009. Na nostructured photovoltaics for space power. Journal of Na noph otonics 3(1), 031880:1-031880:16. doi:10.11 17/1.3266502

Huo, M., Zhang, X., He, J., 2011. Causality relationship between the photovoltaic market a nd its manufacturing in China, Germany, the US, and Japan. Frontiers in Energy 5(1), 43-48. doi: 10.1007/s11708-010-0135-5

Huo, M-L., Zhang, D-W., 2012. Lessons from photovoltaic policies in China for future development. Energy Policy 51,38-45. doi: 10.1016/j.enpol.2011.12.063

Iizuka, M., 2015. Diverse and uneven pathways towards transition to low ca rbon develo pment: the ca se of solar PV technology in China. Innovation and Development 5(2), 241-261. doi: 10.1080/2157930X.2015.1049850

IRENA, 2016. Renewable Energy and Jobs Annual Review 2016. IRENA, The International Renewable Energy Agency, Ma sdar City. (downloaded on 10 February 2017 from http://www.irena.org/DocumentDownloads/Publications/IRENA_RE_Jobs_Annual_Review_2016.pdf).

Ja cobsson, S., Johnson, A., 2000. The diffusion of renewable energy technology: an a nalytical framework and key issues for resea rch. Energy Policy 28(9), 625-640. doi: 10.1016/S0301-4215(00)00041-0

Jä ger-Wa ldau, A., 2013. PV Status Report 2013. JRC Scientific and Policy Report EUR 26118 EN. Belgium, European Commission. (downloaded on 10 Ja nuary 2017 from https://setis.ec.europa.eu/sites/default/files/reports/JRC_PV_Status_Report_2013.pdf).

Ja ra millo-Nieves, L., del Río, P., 2010. Contribution of Renewable Energy Sources to the Sustainable Development of Islands: An Overview of the Literature and a Research Agenda. Sustainability 2(3), $783-811$.

Jang, S-L., Chen, L-J., Chen, J.H., Chiu, Y-Ch., 2013. Innovation and production in the global solar photovoltaic industry. Scientometrics 94(3), 1021-1036. doi: 10.1007/s11192-012-0907-2

Johnstone, N., Ha scic, I. \& Popp, D., 2010. Renewable Energy Policies and Technological Innovation: Evidence Ba sed on Pa tent Counts. Environmental and Resource Economics, 45(1), 133-155. doi:10.1007/s10640-0099309-1

Kara chalios, K., Thumm, N., Latif, A.A., Roffe, P., Simmons, B. and Amin, T., 2010. Patents and Clean Energy: Bridging the Gap Between Evidence and Policy. Geneva: UNEP, EPO and ICTSD. http://ictsd.org/i/publications/85887.

Kivimaa,P., Kern, F., 2016. Creative destruction or mere niche support? Innovation policy mixes for susta inability transitions. Research Policy 45(1), 205-217. doi: 10.1016/j.respol.2015.09.008

Laursen, K., 2015. Revealed comparative advantage and the a lternatives as measures of international specia lization. Eurasian Business Review, 5(1), pp. 99-115.

Lee, K. \& Ma lerba, F., 2017. Catch-up cycles and changes in industrial lea dership: Windows of opportunity and responses of firms and countries in the evolution of sectoral systems. Research Policy, 46(2), pp. 338-351. doi: 10.1016/j.respol.2016.09.006

Lema, R. \& Lema A. (2012). Technology transfer? The rise of China and India in green technology sectors. Innovation and Development, 2(1), 23-44. doi: 10.1080/2157930X.2012.667206 
Lenardic, D., 2016. Large-Scale PV Power Plants - Top50. [Online] Available at: http://www.pvresources.com/en/top50pv.php [Accessed 8 March 2017].

Lund, H., 2007. Renewable energy strategies for sustainable development. Energy 32(6), 912-919. doi: 10.1016/j.energy .2006.10.017

Lundvall, B.-A.(Ed.), 1992. Na tional Systems of Innovation. Towards a Theory of Innovation and Interactive Learning. Pinter, London and New York.

Li, L., Tan, Z., Wang, J., Xu, J., Cai, Ch., Hou, Y., 2011. Energy conservation and emission reduction policies for the electric power industry in China. Energy Policy 39,3669-3679. doi: 10.1016/j.enpol.2011.03.073

Liu, J., Goldstein, D., 2013. Understanding China's renewable energy technology ex ports. Energy Policy 52, 417-428. doi: 10.1016/j.enpol.2012.09.054

Malerba, F., 2002. Sectoral systems of innovation and production. Research Policy, 31(2), pp. 247-264. doi: 10.1016/S0048-7333(01)00139-1

Ma lerba,F. \& Nelson, R., 2011. Learning and catching up in different sectoral systems: evidence from six industries. Industrial and Corporate Change, 20(6),p. 1645-1675. doi: 10.1093/icc/dtr062

Mints, P., 2014. Top Ten PV Manufacturers from 2000 to Present: A Pictorial Retrospective. Renewable Energy World, Ja nuary 21, 2014.[Online] Availa ble at:http://www.renewableenergyworld.com/articles/2014/01/top ten-pv-manufacturers-from-2000-to-present-a-pictorial-retrospective.html [Accessed 1 March 2017].

Mints, P., 2016.2015 Top Ten PV Cell Ma nufacturers. Renewable Energy World, April 8, 2016. [Online] Available at:http://www.renewableenergyworld.com/articles/2016/04/2015-top-ten-pv-cellmanufacturers.html [Accessed 1 March 2017].

Mowery, D., Nelson, R., 2001. Sources of Industrial Lea dership Studies of Seven Industries. Cambridge University Press, Ca mbridge.

NREL, 2016. Na tional Renewable Energy Laboratory - Photovoltaic Research. [Online] Available at: https://www.nrel.gov/pv/ [Accessed 3 Ja nuary 2017].

Nelson, R.R. (Ed.), 1993. Na tional Innovation Systems: A Comparative Analysis. Oxford University Press, Oxford.

North, D.C., 1990. Institutions, Institutional Change and Economic Performance. Cambridge University Press, Cambridge.

OECD, 2009. OECD Patent Statistics Manual, Pa ris: Orga nisation for Economic Cooperation and Development.

Park, Y.-J., Kim, G., 2012. Estimating the timing of a pickup. KDB Da ewoo Securities Company Report, OCI (010060 KS) Chemicals. (downloaded on 10 February 2017 from https://www.miraeassetdaewoo.com/bbs/maildownload/0904fc5280455c0d).

Platzer, M. D., 2015. U.S. Solar Photovoltaic Manufacturing: Industry Trends, Global Competition, Fe deral Support. CRS Report, R42509. (downloaded on 10 February 2017 from https://fas.org/sgp/crs/misc/R42509.pdf).

Publicover, B., 2017. Hangzhou Fengling finishes 200 MW solar-aquaculture project. PV magazine, January 23 2017. [Online] Available at: https://www.pv-magazine.com/2017/01/23/hangzhou-fengling-finishes-200mw-solar-aquaculture-project/[Accessed 8 March 2017].

Qiang, Z., Honghang, S., Yanxi, L., Yurui, X., Jun, S., 2014. China's solar photovoltaic policy: An analysis based on policy instruments. Applied Energy 129,308-319. doi: 10.1016/j.apenergy.2014.05.014

Quitzow, R., 2015. Dynamics of a policy-driven market: The co-evolution of technological innovation systems for solar photovoltaics in China and Germany. Environmental Innovation and Societal Transitions 17, 126148. doi: 10.1016/j.eist.2014.12.002

Reichardt, K., Rogge, K., 2016. How the policy mix impacts innovation: Findings from company case studies on offshore wind in Germany. Environmental Innovation and Societal Transitions 18, 62-81. doi: 10.1016/j.eist.2015.08.001

Ren, H., Zhou, W., Nakagami, K., 2010. Feasibility Study on Introducing Bu ilding Integrated Photovoltaic System in China and Analysis of the Promotion Policies. In:T. Yao (ed), Zero-Carbon Energy Kyoto 2009. Green Energy and Technology. Springer, Tokyo, pp 380-384. doi: 10.1007/978-4-431-99779-5_62 
Roselund, C., 2016.2015 Poly and wafer rankings. PV Ma gazine, 4/2016, pp. 74-77. (downloaded on 1 March 2017 from http://www.bernreuter.com/fileadmin/user_upload/library/2015-poly-and-wafer-rankings_pvmagazine-04-2016.pdf).

Si-Cheng, W., 1987. Present Situation of Photovoltaic Applications In China. In A. Goetzberger, W. Palz, G. Willeke (Eds.), Seventh E.C. Photovoltaic Solar Energy Conference, pp. 56-60. doi: 10.1007/978-94-0093817-5_10

Shen, W., 2017. Who drives China's renewable energy policies? Understanding the role of industrial corporations. Environmental Development 21,87-97. doi: 10.1016/j.envdev.2016.10.006

Shubbak, M. H., 2017. The Technological System of Photovoltaics: Identification and Analysis with Patent Cla sses. Budapest, The 29th Annual EAEPE Conference, European Association for Evolutionary Political Economy.

Shubbak, M.H., 2018. Innovation capability, network embeddedness and economic performance: Profiling solar power innovators in China. International Journal of Technological Learning, Innovation and Development. 10(3-4), pp. 258-294. doi: 10.1504/IJTLID.2018.093723

Soete, L. G., Wyatt, S. E., 1983. The use of foreign patenting a s an internationally comparable science and technology output indicator. Scientometrics 5(1), 31-54. doi: 10.1007/BF02097176

Statista, 2016. Solar photovoltaic industry - Sta tista Dossier. (downloaded on 1 March 2017 from https://www.statista.com/study/9984/solar-photovoltaic-industry-statista-dossier/).

Valente, S., 2005. Sustainable Development, Renewable Resources and Technological Progress. Environmental \& ResourceEconomics 30(1), 115-125. doi: 10.1007/s10640-004-2377-3

Vedung, E., 1998/2010. Policy Instruments: Typologies and Theories. In: M.-L. Bemelmans-Videc, R.C. Rist, E. Vedung(Eds.), Carrots, Sticks \& Sermons: Policy Instruments \& Their Evaluation. Transaction Publishers, London, pp. 21-58.

Veugelers, R., 2012. Which policy instruments to induce clean innovating? Research Policy 41(10), 1770-1778. doi: 10.1016/j.respol.2012.06.012

Wang, Y-H., Luo, G-L., Guo, Y-W., 2014. Why is there overcapacity in China's PV industry in its early growth stage? Renewable Energy 72, 188-194. doi: 10.1016/j.renene.2014.07.008

Wei, Y-Z., Li, X-W., Lie, Y., Li, W-Z., Yu, P-N., 1981. Photovoltaic Activities and its Applications in China. In: W. Palz (Ed.), Photovoltaic Solar Energy Conference, pp 66-70. doi: 10.1007/978-94-009-8423-3_11

$\mathrm{Wu}, \mathrm{Ch}-\mathrm{Y} ., 2014$. Comparisons of technological innovation capabilities in the solar photovoltaic industries of Taiwan, China, and Korea. Scientometrics 98(1), 429-446. doi: 10.1007/s11 192-013-1 120-7

$\mathrm{Wu}, \mathrm{Ch}-\mathrm{Y}$., Mathews, J.A., 2012. Knowledge flows in the solar photovoltaic industry: Insights from patenting by Taiwan, Korea, and China. Research Policy 41 (3), 524-540. doi: 10.1016/j.respol.2011.10.007

Wu, H., Hou, Y., 2011. Recent Development of Grid-connected PV Systems in China. Energy Procedia 12, 462 - 470. doi: 10.1016/j.egypro.2011.10.062

Yang, H., Wang, H., Yu, H., Xi, J., Cui, R., Chen, G., 2003. Status of photovoltaic industry in China. Energy Policy 31(8), 703-707. doi: 0.1016/S0301-4215(02)00121-0

Yu, Y., Li, H., Ba o, H., 2016. Price dynamics and market relations in solar photovoltaic silicon feedstock trades. Renewable Energy 86, 526-542. doi: 10.1016/j.renene.2015.08.069

Zhang, F., Ga lla gher, K.S., 2016. Innovation and technology transfer through global value chains: Evidence from China's PV industry. Energy Policy 94, 191-203. doi: 10.1016/j.enpol.2016.04.014

Zhang, S., Andrews-Speed, P., Ji, M., 2014. The erratic path of the low-carbon transition in China: Evolution of solar PV policy. Energy Policy 67,903-912. doi: 10.1016/j.enpol.2013.12.063

Zhang, S., He, Y., 2013. Analysis on the development and policy of solar PV power in China. Renewable and Susta inable Energy Reviews 21,393-401. doi: 10.1016/j.rser.2013.01.002

Zhang, W., White, S., 2016. Overcoming the lia bility of newness: Entrepreneurial action and the emergence of China's private solar photovoltaic firms. Research Policy 45(3), 604-617. doi: 10.1016/j.respol.2015.11.005

Zha o,Z-Y., Zhang, S-Y., Zuo, J., 2011. A critical analysis of the photovoltaic power industry in China - From dia mond model to gear model. Renewable and Sustainable Energy Reviews 15(9), 4963-4971. doi: 10.1016/j.rser.2011.07.057 
APPENDIX - TABLE A: THE MAIN FIRM ACTORS IN THE CHINESE TIS OF PV TECHNOLOGY

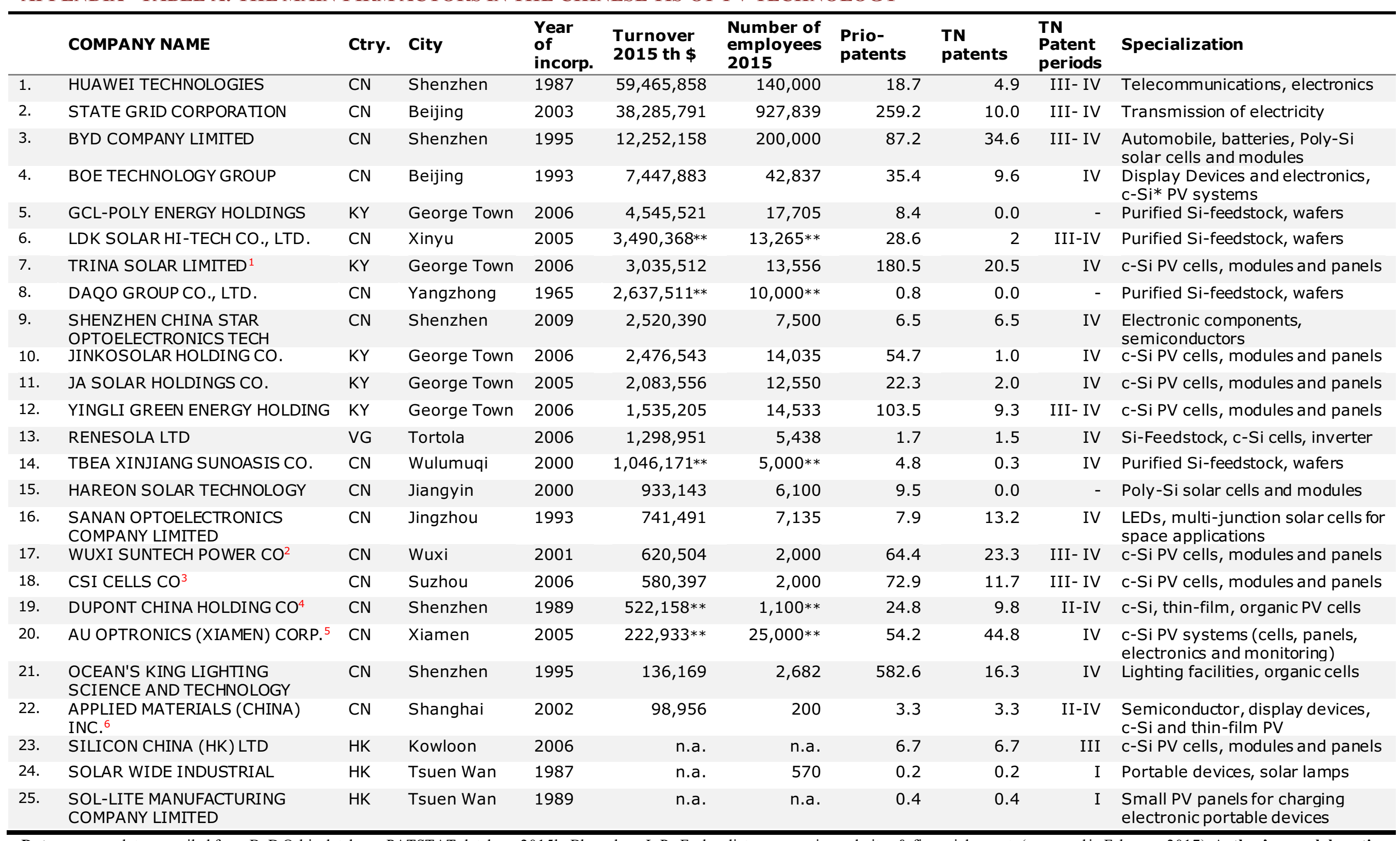

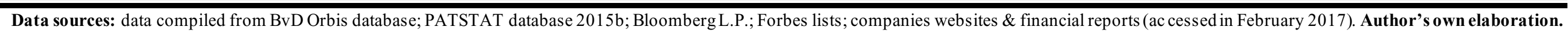


Notes:

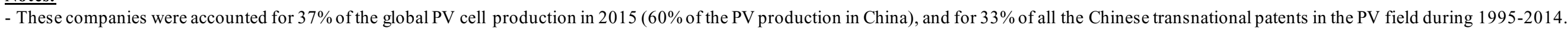

- Companies are sorted by their turnover values (operating revenue) in a descending order.

* c-Si: Crystalline silicon both mono- and polycrystalline technologies. ** Data is for 2014.

${ }^{1}$ Changzhou Trina Solar Energy Co., Ltd. in Changzhou, China, was incorporated in 1997.

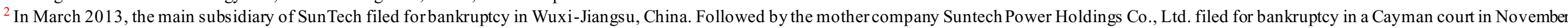

2013. The primary manufacturing unit: Wuxi SunTech Power Co. Ltd. was sold to mid-size solar manufacturer Shunfeng Photovoltaic International Ltd. for $\$ 492$ million in November 2013.

${ }^{3}$ The mother company Canadian Solar Inc. was incorporated in Guelph, Canada in 2001.

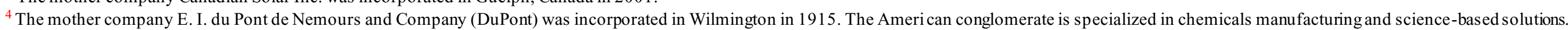

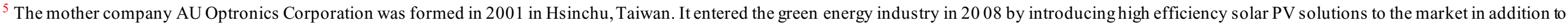
its traditional display products.

${ }^{6}$ The mother company Applied Materials Inc. was incorporated in Santa Clara, USA in 1973. It is specialized in semiconductor sy stems, LCD/LED display, c-Si and thin-film PV cells and panels.

\section{APPENDIX - TABLE B: FDI AND M\&A DEALS: FOREIGN FIRMS HAVING ACQUISITIONS AND SUBSIDIARIES IN CHINA}

\begin{tabular}{|c|c|c|c|c|c|c|}
\hline Acquirer Name & $\begin{array}{l}\text { Acquirer } \\
\text { Country }\end{array}$ & Target Name & $\begin{array}{l}\text { Target } \\
\text { Country }\end{array}$ & Deal Type & $\begin{array}{l}\text { Deal Value } \\
\text { th EUR }\end{array}$ & $\begin{array}{l}\text { Announced } \\
\text { Date }\end{array}$ \\
\hline BASF AG & $\mathrm{DE}$ & $\begin{array}{l}\text { BASF AG AND OTHER JOINT VENTURE PARTNERS' CHEMICAL } \\
\text { MANUFACTURING JOINT VENTURE }\end{array}$ & $\mathrm{CN}$ & Joint venture $100 \%$ & n.a. & $03 / 07 / 2000$ \\
\hline ASAHI KASEI CORPORATION & JP & RESIN PRODUCTION AND SALES JOINT VENTURE & $\mathrm{CN}$ & Joint venture $100 \%$ & n.a. & $26 / 03 / 2002$ \\
\hline KYOCERA CORPORATION & JP & KYOCERA (TIANJIN) SALES AND TRADING CO Ltd & $\mathrm{CN}$ & Joint venture $100 \%$ & $126,526.13$ & $01 / 01 / 2003$ \\
\hline BASF AG & DE & SHANGHAI LIANHENG ISOCYANATE CO., Ltd & $\mathrm{CN}$ & Joint venture $100 \%$ & $310,396.17$ & $31 / 03 / 2003$ \\
\hline KYOCERA CORPORATION & JP & KYOCERA (TIANJIN) SOLAR ENERGY CO., Ltd & $\mathrm{CN}$ & Joint venture $100 \%$ & $1,801.14$ & $05 / 06 / 2003$ \\
\hline $\begin{array}{l}\text { EI DU PONT DE NEMOURS \& } \\
\text { COMPANY }\end{array}$ & US & $\begin{array}{l}\text { GUANGZHOU MONTELLI MATERIAL TECHNOLOGY } \\
\text { CORPORATION }\end{array}$ & $\mathrm{CN}$ & Acquisition $100 \%$ & n.a. & $05 / 03 / 2004$ \\
\hline SANYO ELECTRIC CO., LTD & JP & NINGBO GP SANYO ENERGY CO Ltd & $\mathrm{CN}$ & Joint venture $100 \%$ & $20,502.50$ & $01 / 07 / 2004$ \\
\hline SHARP CORPORATION & JP & NANJING SHARP ELECTRONICS CO., Ltd & $\mathrm{CN}$ & $\begin{array}{l}\text { Acquisition increased } \\
\text { from } 91 \% \text { to } 100 \%\end{array}$ & $7,160.83$ & $16 / 10 / 2005$ \\
\hline AU OPTRONICS CORPORATION & TW & DARWIN PRECISIONS (XIAMEN) CORPORATION & $\mathrm{CN}$ & Joint venture $100 \%$ & $14,600.25$ & $13 / 03 / 2006$ \\
\hline $\begin{array}{l}\text { MITSUBISHI ELECTRIC } \\
\text { CORPORATION }\end{array}$ & JP & $\begin{array}{l}\text { MISUBISHI ELECTRIC CORPORATION AND BAODING TIANWEI } \\
\text { GROUP CO. HIGH-VOLTAGE SWITCHGEAR JOINT VENTURE }\end{array}$ & $\mathrm{CN}$ & Joint venture $100 \%$ & $11,525.37 *$ & $26 / 07 / 2006$ \\
\hline $\begin{array}{l}\text { HONEYWELL INTERNATIONAL } \\
\text { INC. }\end{array}$ & US & LONON INDUSTRY CO., LTD'S BUSINESS AND ASSETS & $\mathrm{CN}$ & Acquisition $100 \%$ & $21,973.69 *$ & $08 / 01 / 2008$ \\
\hline AU OPTRONICS CORPORATION & TW & QINGDAO HAIER OPTRONICS CO., Ltd & $\mathrm{CN}$ & Joint venture $100 \%$ & $5,282.20$ & $29 / 04 / 2010$ \\
\hline SHIN-ETSU CHEMICAL CO. Ltd & JP & SHIN-ETSU (JIANGSU) OPTICAL PREFORM CO Ltd & $\mathrm{CN}$ & Joint venture $100 \%$ & $494,036.47$ & $27 / 10 / 2010$ \\
\hline
\end{tabular}


CANADIAN SOLAR INC.

CA

CANADIAN SOLAR INC., SUZHOU NEW DISTRICT ECONOMIC DEVELOPMENT GROUP CORPORATION and SUZHOU SCIENCE AND TECHNOLOGY CITY DEVELOPMENT CO. Ltd' PV cell production factory

SINOCHEM LANTIAN HONEYWELL NEW MATERIAL CO., Ltd

MITSUBISHI ELECTRIC LOW VOLTAGE EQUIPMENT (XIAMEN) CO., Ltd

INC.

MITSUBISHI ELECTRIC

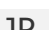

CORPORATION

MITSUBISHI ELECTRIC

JP

HEFEI KINGHOME MITSUBISHI ELECTRIC HOME APPLIANCES TECHNOLOGY DEVELOPMENT CO.

*estimated value. Da ta Source: Bureau van Dijk - Zephyr Database (version 30.0)-2017. Author's own elaboration

$\mathrm{CN}$ Joint venture $100 \%$

n.a. $01 / 06 / 2011$
Joint venture $100 \%$

Joint venture $100 \%$

Joint venture $100 \%$ n.a. $10 / 10 / 2011$

$4,730.02 \quad 14 / 12 / 2011$

$4,740.15 \quad 20 / 06 / 2013$

\section{APPENDIX - TABLE C: M\&A DEALS: CHINESE PV FIRMS ACQUIRING FOREIGN FIRMS}

\begin{tabular}{|c|c|c|c|c|c|c|}
\hline Acquirer Name & $\begin{array}{l}\text { Acquirer } \\
\text { Country }\end{array}$ & Target Name & $\begin{array}{l}\text { Target } \\
\text { Country }\end{array}$ & Deal Type & $\begin{array}{l}\text { Deal Value } \\
\text { th EUR }\end{array}$ & $\begin{array}{l}\text { Announced } \\
\text { Date }\end{array}$ \\
\hline $\begin{array}{l}\text { BEIJING ORIENTAL ELECTRONICS } \\
\text { TECHNOLOGY GROUP CO., LTD }\end{array}$ & $\mathrm{CN}$ & $\begin{array}{l}\text { HYNIX SEMICONDUCTOR INC.'S TFT LCD } \\
\text { BUSINESS }\end{array}$ & $\mathrm{KR}$ & Acquisition $100 \%$ & $354,160.00$ & $27 / 09 / 2002$ \\
\hline SUNTECH POWER HOLDINGS CO. LTD & KY & MSK CORPORATION & $\mathrm{JP}$ & Acquisition $66.67 \%$ & $84,155.50$ & $02 / 08 / 2006$ \\
\hline HAIER GROUP CORPORATION & $\mathrm{CN}$ & SANYO UNIVERSAL ELECTRIC PCL & $\mathrm{TH}$ & Acquisition majority stake & $13,807.36 *$ & $27 / 10 / 2006$ \\
\hline SUNTECH POWER HOLDINGS CO. LTD & KY & KSL-KUTTLER AUTOMATION SYSTEMS GMBH & $\mathrm{DE}$ & Acquisition $100 \%$ & $34,100.00$ & $28 / 01 / 2008$ \\
\hline GCL-POLY ENERGY HOLDINGS LTD & KY & JOINT LOYAL HOLDINGS LTD & VG & Acquisition $100 \%$ & $14,765.94 *$ & $11 / 08 / 2008$ \\
\hline SUNTECH POWER HOLDINGS CO. LTD & KY & EL SOLUTIONS INC. & US & Acquisition $100 \%$ & n.a. & $02 / 10 / 2008$ \\
\hline LDK SOLAR COMPANY LTD & KY & $\begin{array}{l}\text { Q-CELLS SE'S AND LDK SOLAR CO., LTD'S } \\
\text { unnamed PV systems joint venture }\end{array}$ & $\mathrm{DE}$ & Joint venture $100 \%$ & n.a. & $08 / 04 / 2009$ \\
\hline LDK SOLAR COMPANY LTD & $\mathrm{KY}$ & SOLAR GREEN TECHNOLOGY SPA & IT & Acquisition $70 \%$ & n.a. & $14 / 07 / 2009$ \\
\hline LDK SOLAR COMPANY LTD & KY & SOLAR POWER INC. & US & Acquisition $70 \%$ & $23,227.99 *$ & $06 / 01 / 2011$ \\
\hline JA SOLAR HOLDINGS CO., LTD & KY & SILVER AGE HOLDINGS LTD & VG & Acquisition $100 \%$ & $133,917.94$ & $01 / 07 / 2011$ \\
\hline HUAWEI TECHNOLOGY CO., LTD & $\mathrm{CN}$ & CENTRE FOR INTEGRATED PHOTONICS LTD, THE & GB & Acquisition $100 \%$ & n.a. & $25 / 01 / 2012$ \\
\hline $\begin{array}{l}\text { AIKO SOLAR ENERGY TECHNOLOGY } \\
\text { CO LTD }\end{array}$ & $\mathrm{CN}$ & SCHEUTEN SOLARWORD SOLIZIUM GMBH & $\mathrm{DE}$ & Acquisition $100 \%$ & n.a. & $12 / 06 / 2012$ \\
\hline HAREON SOLAR TECHNOLOGY CO. Ltd & $\mathrm{CN}$ & BRILLIANT HARVEST 003 LTD & GB & Acquisition $100 \%$ & $2,321.58$ & $13 / 02 / 2014$ \\
\hline STATE GRID CORPORATION of CHINA & $\mathrm{CN}$ & ROSSIISKIE SETI OAO & RU & Joint venture $100 \%$ & n.a. & $13 / 10 / 2014$ \\
\hline HISENSE ELECTRIC CO., LTD & $\mathrm{CN}$ & SHARP ELECTRONICA MEXICO SA DE CV & MX & Acquisition $100 \%$ & $19,848.90$ & $31 / 07 / 2015$ \\
\hline
\end{tabular}

*estimated value. Da ta Source: Bureau van Dijk - Zephyr Da tabase (version 30.0) - 2017. Author's own ela boration. 
APPENDIX - TABLE D: TOP PRIORITY-FILING APPLICANTS OF CHINESE INVENTIONS

\begin{tabular}{rlc|lc}
\hline Firm Applicant Name & $\begin{array}{l}\text { Number of } \\
\text { Applications }\end{array}$ & Non-Firm Applicant Name & $\begin{array}{c}\text { Number of } \\
\text { Applications }\end{array}$ \\
\hline 1. & Oceans King Lighting Science & 582.6 & University Zhejiang & 151.6 \\
2. & State Grid Corp China & 259.2 & University Tsinghua & 112.0 \\
3. & Shanghai Huali Microelect Corp & 181.1 & Suzhou Inst Nano Tech \& Nano B & 110.4 \\
4. & Changzhou Trina Solar Energy & 180.5 & Inst Semiconductors CAS & 105.7 \\
5. & Jifu New Energy Tech Shanghai & 122.4 & University Electronic Science \& Tech & 93.3 \\
6. & Semiconductor Mfg Int Shanghai & 113.2 & University Shanghai Jia otong & 90.2 \\
7. & Yingli SolarChina Co Ltd & 103.5 & China Electric Power Res Inst & 88.5 \\
8. & BYD Co Ltd & 87.2 & University North China Elec Power & 85.7 \\
9. & Altusvia Energy Taicang Co Ltd & 81.3 & University Huazhong Science Tech & 84.4 \\
10. & Chengdu Juhe Technology Co Ltd & 73.7 & University Sun Yat Sen & 78.7 \\
11. & Suzhou CSI Solar Power Tech. & 72.9 & University Southeast & 76.4 \\
12. & Eging Photovoltaic Tech Co Ltd & 70.8 & University Shanghai & 71.6 \\
13. & Wuxi SunTech Power Co Ltd & 64.4 & Inst Of Microelectronics CAS & 71.0 \\
14. & Hongfujin Prec Ind Shenzhen & 59.9 & University Nankai & 66.9 \\
15. & Jinko SolarCo Ltd & 54.7 & Shanghai Tech Physics Inst & 63.8 \\
16. & AU Optronics Corp & 54.2 & University Tianjin Technology & 54.9 \\
\hline
\end{tabular}

Source: Author's calculations. Data extracted from PATSTAT 2015.

\section{LIST OF ABBREVIATIONS}

\begin{tabular}{|c|c|}
\hline 1G & First generation technologies \\
\hline 2G & Second generation technologies \\
\hline 3G & Third generation technologies \\
\hline AD & anti-dumping duties \\
\hline BP & British Petroleum \\
\hline BvD & Bureau van Dijk \\
\hline c-Si & Crystalline Silicon \\
\hline CdTe & Cadmium telluride thin-film cells \\
\hline CIGS & Copper Indium Ga llium Selenide thin-film cells \\
\hline CVD & Anti-subsidy duties (Countervailing duties) \\
\hline DGC & Duolun Golden Concord (mining company) \\
\hline DOC & US Commerce Department \\
\hline EPO & European Pa tent Office \\
\hline $\mathbf{E U}$ & European Union \\
\hline FDI & Foreign direct investment \\
\hline FIT & Feed-in tariffs \\
\hline FYP & Five-yearplan \\
\hline GaAs & Gallium Arsenide \\
\hline IPO & InitialPublic Offering \\
\hline IPR & Intellectual property rights \\
\hline M\&A & Mergers and acquisition deals \\
\hline MDI & Methylene diphenyl diisocyanate \\
\hline NCIP & Net charges for using intellectual property \\
\hline PATSTAT & Worldwide Patent Statistical Da tabase \\
\hline PCT & PatentCooperation Treaty \\
\hline PV & Photovoltaics \\
\hline R\&D & Research and development \\
\hline RTA & Revealed Technology Advantage \\
\hline $\mathrm{SiO}_{2}$ & Silicon dioxide (quartz sand) \\
\hline TIS & Technological Innovation System \\
\hline US & United States of America \\
\hline$\eta$ & Cell efficiency \\
\hline
\end{tabular}

